\title{
APPLICATION OF MOLECULAR TOOLS IN ANIMAL BREEDING, CROP SCIENCE, FOOD CONTROL AND AGROBIODIVERSITY IN THE REPUBLIC OF MACEDONIA
}

\author{
Zoran T. Popovski ${ }^{1,5^{*}}$, Blagica Tanaskovska ${ }^{1}$, ElizabetaMiskoska - Milevska ${ }^{2}$, Tome Nestorovski ${ }^{1}$, \\ Koco Porcu ${ }^{3}$, Katerina Bandzo-Oreshkovikj ${ }^{4}$, Milica Svetozarevic ${ }^{5}$, Zimera Saiti ${ }^{5}$, Macdonald Wick ${ }^{6}$
}

\author{
${ }^{1}$ Department of Biochemistry and Genetic Engineering, Faculty of Agriculture Sciences and Food, \\ Ss. Cyril and Methodius University, Skopje, Republic of Macedonia \\ ${ }^{2}$ Department of Food Quality and Safety, Faculty of Agriculture Sciences and Food, \\ Ss. Cyril and Methodius University, Skopje, Republic of Macedonia \\ ${ }^{3}$ Livestock Department, Faculty of Agriculture Sciences and Food, Ss. Cyril and Methodius University, \\ Skopje, Republic of Macedonia \\ ${ }^{4}$ Department of Plant Protection, Institute of Agriculture, Ss. Cyril and Methodius University, \\ Skopje, Republic of Macedonia \\ ${ }^{5}$ Laboratory for Protein and DNA Technology, Faculty of Technology and Metallurgy, \\ Ss. Cyril and Methodius University, Skopje, Republic of Macedonia \\ ${ }^{6}$ Department of Animal Science, College of Agriculture, Environmental and Food Sciences, \\ Ohio State University, Columbus, OH, USA \\ e-mail:zoran_popovski@yahoo.com
}

\begin{abstract}
Molecular methods have become non-replaceable for the improvement of food production and its control. The Department for Biochemistry and Genetic Engineering (DBGE) as a part of the Faculty of Agriculture Sciences and Food is a crucial entity using molecular techniques in different areas of agriculture and livestock production. DBGE is mainly dealing with marker assisted selection (MAS), evolutionary studies; determine the origin of food products; enzyme analysis in food processing; transcriptional and translational analyses; molecular detection of plant viruses; and GMO analysis. The target molecules were proteins, RNA and DNA. MAS is systematically applied in animal breeding in Macedonia using RYR-1, $\kappa$ and $\alpha$ S1-casein genes. Evolutionary studies were performed using DNA microsatellites to estimate genetic distance among autochthonic strains of sheep and tomato varieties. The identification of food products origin and gender identification in fish were done using protein profiling. Gene expression was studied analysing different growth factors and inhibitors at RNA level. More than 3.000 plant and animal samples were analysed in the Laboratory for biochemistry and molecular biology. GMO laboratory as a part of the DBGE is the first authorized facility for GMO testing of food and feed samples. In more than 100 samples RT PCR methods were used.
\end{abstract}

Key words: livestock; crops; food; molecular tools; Macedonia

\section{INTRODUCTION}

The premise on which the recombinant DNA technology is based is that genetic information is a resource that can be manipulated in different ways to achieve certain goals in basic and applied science [1]. Application of modern molecular methods in selection of crops and livestock has become a cru- cial factor in the improvement of food production. It is now possible to identify, characterize and manipulate individual genes [2].

At certain sites along the genomes the sequences vary between individuals. These sites, where differences in DNA sequence occur, are known as molecular markers. When differences in DNA occur within genes, these differences have the 
potential to affect the function of the gene and hence the phenotype of the individual. Molecular markers are wide and effective tools for efficient selection of desired qualitative and quantitative agronomical traits because the markers are based on the genotypes and not influenced by the environmental factors [3]. However, most molecular markers are not associated with a visible phenotype. Based on the knowledge about molecular markers, specific approaches in selection called marker assisted selection (MAS) have been developed. In countries where the economic environment supports high input agriculture, there has been a dramatic increase in the level of productivity from the selective improvement of livestock using MAS. The major challenge that molecular geneticists face is the identification of markers for genes that control the phenotypic variation in the target traits. The most effective markers are the functional mutations within the trait genes. Once the functional polymorphism is known it is possible to predict the effect of particular alleles in a population. Therefore, so called 'direct' markers are more useful than 'linked' markers for predicting the phenotypic variation of target traits within a population [4].

Studies on genetic polymorphisms in animal breeding are closely related to production traits and for this purpose, techniques capable of detecting small variations in the DNA sequence are used. Djedović et al. used these molecular techniques to obtain more data about the individual genome structure [5].

Marker assisted selection in crop production may facilitate agronomical and biochemical traits [3, 6]. The main types of "linked" molecular markers are DNA microsatellites or simple sequence repeats (SSR), and single nucleotide polymorphisms (SNP) [3]. The reproducibility, co-dominance, relative abundance and complete genome coverage of SSR markers have made them one of the most useful tools for detecting genetic diversity, genetic linkage mapping, association mapping and evolution analysis [7].

Genetic modification is a method of introducing new genes into an organism. It is a method of altering an organism without copying (cloning) it. A new genetically modified organism (GMO) or transgenic organism contains newly introduced DNA (a recombinant DNA construct) that imparts a new trait to an organism. Beside the continuous controversies and dilemmas about the possible risks of their application, there are substantial achievements provided by a variety of transgenic plants. On the other hand "biopharming" refers to the production of biopharmaceuticals, based on heterologous genes inserted into different genomes. Various recombinant products from transgenic organisms have been produced, including: human insulin, human growth factor, antibodies, protein antigens, and several enzymes [1]. The accelerated development of GMOs during the past twenty years has raised a new set of questions about the release and traceabilityof such GMOs and their possible adverse effects on the safety of both the environment and the consumer [8]. Different methods (qualitative or quantitative) linked to GMO detection, which are divided in protein and DNA based methods should be registered in GMO Detection Method Database (GMDD). All these different methods used by GMO detection laboratories need to be validated and accredited according to ISO 17025 standard [9]. There is a clear need for global harmonization and standardization of the methods used for sampling and for different methods used to perform GMO detection analysis [10].

In addition, the molecular tools have an irreplaceable role in detection and characterization of causative agents for crop diseases, especially viruses. These agents can be detected using the Double Antibody Sandwich - Enzyme Linked Immune Sorbent Assay (DAS-ELISA) method at the protein level, while PCR based techniques are used for detection at the RNA/DNA level.

Protein and DNA based methods are widely used in food control especially in terms of determination of its quality and origin. Authentication of milk and meat, as well as their derived products, is important because fraudulent incorporation of nondeclared raw materials, during technological processing, can cause problems related to intolerance or allergy, ethical objections and legal requirements [11].

Also, molecular methods are suitable tools for the analysis of the purity of the enzymes used in food processing industries. Reproducible and standardized methods need to be developed and implemented in order for data from different sources to be reliably interpreted.

The aim of this article is to make a review on the application of molecular methods in agricultural sector in the Republic of Macedonia in the past twenty years.

\section{EXPERIMENTAL SECTION}

Applications of molecular tools in livestock and crop production, agro-biodiversity and food control in the Republic of Macedonia were implemented by the Department of Biochemistry and Genetic Engineering as a part of Faculty of Agricultural Sciences and Food in Skopje. In the past 
almost 20 years more than 3,000 animal, plant, and food samples were analyzed in the Biochemistry and Molecular Biology lab and GMO lab. The analyses were performed on both the protein and nucleic acid levels.

Targeted protein molecules were analyzed using electrophoretic and immunological techniques. Sodium Dodecyl Sulfate - Polyacrylamide Gel Electrophoresis (SDS - PAGE) was the electrophoretic technique of choice for the detection and identification of proteins for the investigation of gender specific milk and muscle specific proteins, seed proteins and in the estimation of chymosin purity. Starch Gel Electrophoresis (SGE) was used in characterizing polymorphisms in sheep hemoglobin. ELISA as an immunochemical based technique was employed in the detection of the CP4 EPSPS protein which is the result of the expression of an inserted gene for the genetic modification for glyphosate herbicide tolerance of different crops.

Nucleic acid molecules of interest in these studies were analyzed using PCR based methods. The methods include reverse transcription, digestion, hybridization, fragment analysis, sequencing and Real Time PCR. Firstly, the extraction of RNA and or DNA was done using appropriate kits for isolation of nucleic acids or by "in house" developed techniques. RNA was usually extracted using the TRIzol ${ }^{\circledR}$ method, plant DNA using Cetyl trimethylammonium bromide (CTAB) method, animal DNA using Promega kit, while DNA from processed food samples was done using so called PREP Plant X kit from SureFood, for delicate samples. Isolated RNA was turned into complementary DNA using a commercial kit for reverse transcription. The crucial step, after the extraction of nucleic acids, was the Polymerase Chain Reaction (PCR), which was performed using appropriate sets of primers under previously optimized conditions [12]. Polymorphism in marker genes was usually determined using Restriction Fragment Length Polymorphism (RFLP) for Ryanodine Receptor 1 (RYR-1) gene in swine genome, $\kappa$-casein in cattle genome and $\alpha \mathrm{S} 1$ casein in the sheep genome. Hybridization of amplified DNA was performed for confirmation of mutation in the RYR-1 gene. Endpoint PCR was used for the detection of "housekeeping or reference" and inserted genes during the GMO analyses. Quantification of GMO was done by Real Time PCR using commercial kits specifically designed for such purposes. Evolutionary studies on autochthonic strains of Pramenka sheep breed and local tomato varieties were based on analysis of microsatellite DNA. Determination of genetic distance was done using PCR, followed by fragment analysis using LiCor gel system for sheep strains which is based on capillary electrophoresis for tomato varieties. RNA plant viruses were analyzed using reverse transcription, followed by PCR and ending with DNA sequencing. The potential for muscle growth in Koi carp was determined using simultaneous extraction of RNA and DNA from the same sample and calculation of the RNA/DNA ratio.

During the studies, presented in the previous section, a few innovations and modifications of the existing methods were made. On a protein level simple, efficient techniques were developed for the identification of specific milk and meat proteins from different origin, the determination of chymosin purity and a reliable technique to determine the gender in Koi carp using a female specific protein. At the nucleic acid level, the polymorphism of RYR-1 in the swine genome was confirmed for the first time using dot-blot hybridization, while the detection of housekeeping and inserted genes in GMO detection was done using duplex PCR, instead of individual PCR reactions.

\section{RESULTS AND DISCUSSION}

The achievements of these studies are separated into the following three sections: animal breeding, crop science and food control.

\section{Animal breeding}

In the past two decades, molecular tools in animal science have been applied to study polymorphisms in hemoglobin and as1-casein in sheep breeding, $\kappa$-casein in cattle breeding and the presence of porcine stress syndrome in swine breeding. In the field of sheep breeding, microsatellite DNA as a tool for the determination of genetic distance between domestic strains of Pramenka sheep was analyzed. Growing potential in fisheries was analyzed comparing RNA/DNA and the expression level in white muscles in Koi carp breeding. A female specific protein was investigated as a tool for gender determination. In all these mentioned cases, markers were analyzed on protein or DNA level promoting MAS in livestock production and protection of endangered breeds of domestic animals in the Republic of Macedonia.

\section{Molecular characterization of porcine stress syndrome in the Republic of Macedonia}

Porcine stress syndrome (PSS) is a serious problem in swine breeding that has negative implications on the pork production. One of the causes for PSS is a point mutation in RYR-1 gene that is 
responsible for the transport of $\mathrm{Ca}^{++}$in the sarcoplasmic reticulum of the muscle cells. The molecular basis of PSS was determined in the first decade of twentieth century [13] and it enabled an application of molecular methods in the detection of PSS. The first step in all those methods is amplification of the DNA region around nucleotide 1843 of the RYR-1 gene where a mutation $\mathrm{C} \rightarrow \mathrm{T}$ is occurred. After that, the amplified fragment is analyzed using RFLP [14] or dot-blot hybridization based on our innovation. [15]. The aim of this study was to determine the presence of PSS in the swine population in the Republic of Macedonia in the different categories and breeds, to find out the correlation between the genotypes for PSS with some biochemical parameters and to determine the influence of PSS on production and reproductive attributes in the studied animals. Specifically, 278 animals were included in this study. Genotyping of PSS was performed using PCR based techniques (Figure 1).
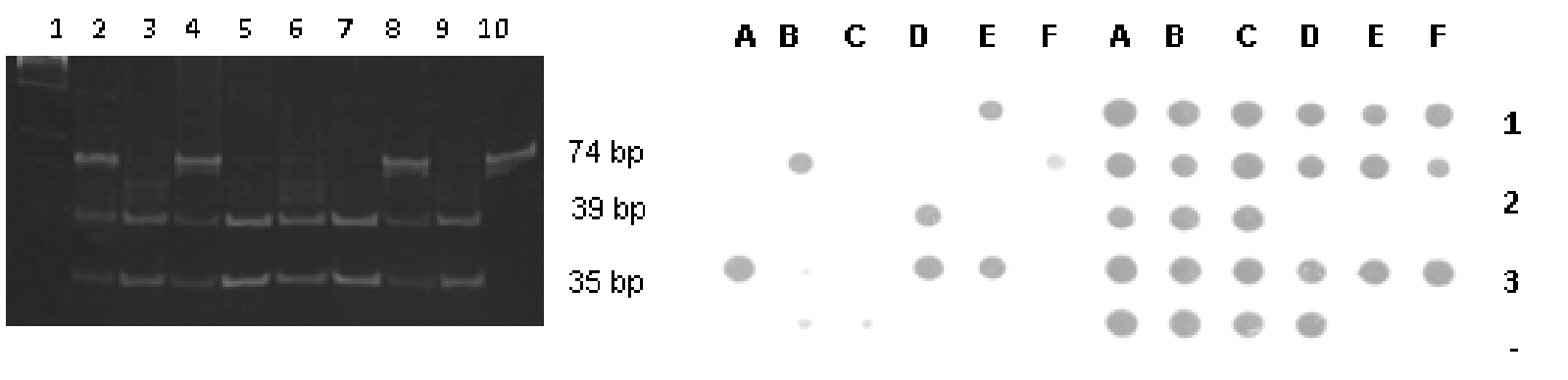

Figure 1. Genotypes of PSS

A) $13 \%$ polyacrylamide gel electrophoresis of the digestions of PCR products from a RYR-1 gene using restriction enzyme Hha I,.ln 1 DNK ladder, Ins 2, 4, 8 heterozygous with a genotype Nn; lns 3,5,6,7,9 normal animals with a genotype NN; ln 10 homozygous with genotype nn. B) Dot-blot hybridization. A4, B2, D4, E1 I E4 heterozygous with a genotype Nn, E3 homozygous with genotype nn, all others are normal with a genotype $\mathrm{NN}$.

PSS is the most frequent in Landrace breed with allele frequency (AF) of mutant allele of 0.211 . From the biochemical perspective, the highest correlation with the genotype for PSS showed the enzymes creatine phosphokinase (CPK), lactate dehydrogenase (LDH) and aspartate aminotransferase (AST) which were initially reported in our study [16]. The results related to the influence of the genotype for PSS on some productive and reproductive traits in boars showed that the stress sensitive animals with genotype nn have less food conversion, better daily gain, thinner back fat and higher percentage of lean meat, compared with stress free animals. But the level of mortality and appearance of so called pale, soft and exudative meat is higher in stress susceptible animals. Analysis of some reproductive traits showed that stress sensitive sows have smaller average of live born and successfully refused piglets compared with heterozygous animals (stress careers). It is obvious that the stress syndrome has serious implications on the quality of the pork meat mainly because of the rapid drop in $\mathrm{pH}$ immediately postmortem resulting in a higher percentage of pale, soft and exudative (PSE) meat in carcasses of stress susceptible animals. Thus, it will be necessary in the future to undertake measures for the systematic exclusion of stress sensitive and stress carrying animals in the further breeding strategies [17].

\section{Determination of milk protein polymorphisms in cow milk using SDS PAGE electrophoresis}

Milk proteins are divided into two fractions: milk serum and caseins. The major protein components of milk serum are $\alpha$-lactalbumin $(\alpha$-La) and $\beta$-lactoglobulin $(\beta-\mathrm{Lg})$. In the casein fraction, five proteins have been intensively studied: $\alpha_{\mathrm{S1}}$-casein $\left(\alpha_{\mathrm{S} 1}-\mathrm{Cn}\right), \alpha_{\mathrm{S} 2}$-casein $\left(\alpha_{\mathrm{S} 2}-\mathrm{Cn}\right), \beta$-casein $(\beta-\mathrm{Cn}), \gamma-$ casein $(\gamma-\mathrm{Cn})$ and $\kappa$-casein $(\kappa-\mathrm{Cn})$. Electrophoretic analyses of milk proteins demonstrated the existence of different variants for these proteins [18], all of them determined by co-dominant alleles of the closely linked autosomal genes. In this case our task was to develop an appropriate technique for the discrimination of different types of $\kappa$-casein in cow milk. As a starting material for such analysis we used serum and lyophilized milk. We developed a modified approach in the separation of polymorphic types of those proteins based on molecular weight and isoelectric point [19]. Using this method we found six different haplotypes of milk proteins (Figure 2).

Due to the low resolution of polymorphic fractions and impossibility of determining the polymorphism in each milk protein, we continued with the molecular characterization of separate milk genes using DNA methods. 


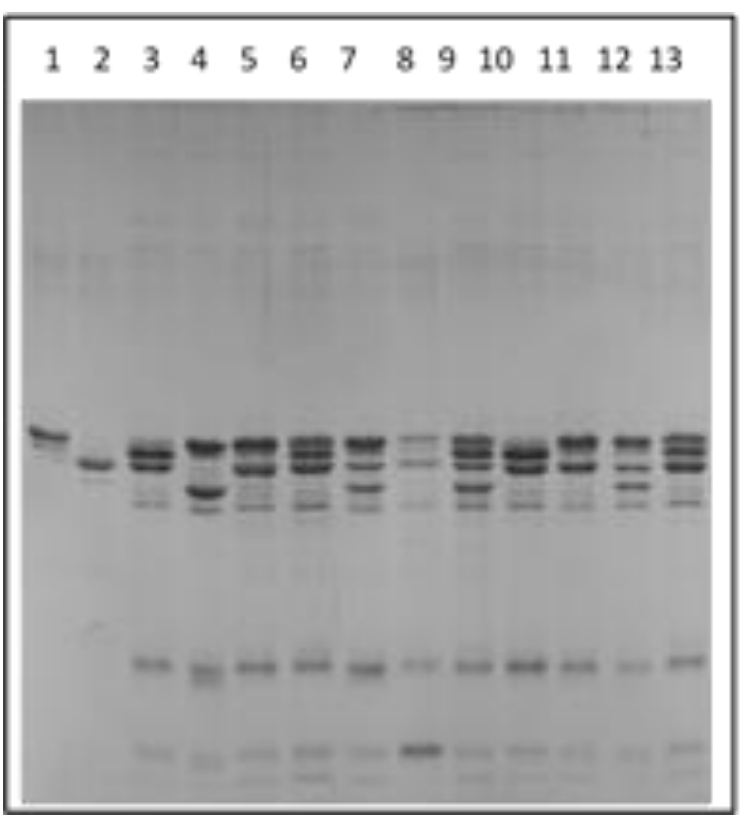

Figure 2.12.5\% SDS-PAGE of analyzed milk samples. $\ln 1 \alpha$ casein, $\ln 2 \beta$ casein, $\ln 8$ mix milk standards, lns $3,4,5,6,7,9,10,11,12$ and 13 milk samples from different animals

\section{Kappa $\kappa$-casein polymorphisms in Holstein- Friesian cattle in the Republic of Macedonia}

Kappa $\kappa$-casein is one of the five milk casein proteins and is the product of the gene positioned on the $6^{\text {th }}$ bovine chromosome. It plays an essential role in stabilizing the casein micelles and therefore has a significant influence on milk manufacturing properties. Genetic variants of $\kappa$-casein have been extensively studied in cattle at the protein and DNA levels. Numerous alleles have been revealed [20]. Two of 14 allele variants, A and B, are particularly frequent in the cattle population, in Macedonia. According to their allele frequency, the A allele is considered to be the initial type of allele [21]. The polymorphisms that appear in the $\kappa$-casein gene are associated with the milk yield and its technological properties [22]. Identification of these polymorphisms opens possibilities of further improvements in the dairy industry. $\kappa$-casein is used as an important marker in the selection of dairy cows. A recent study was undertaken to determine the presence of $\kappa$-casein genotypes in Holstein-Friesian cows in Macedonia and to check if any correlation exists between the genotype and some of the biochemical properties of their milk. Technological properties of milk obtained from dairy cows with different genotypes were also checked to confirm any link among them. The analyses were done on DNA isolated from blood or semen of 227 black- white Holstein-Friesian cattle. Genotyping of $\kappa-$ casein polymorphisms was done by PCR-RFLP using three different restriction enzymes. According to the electrophoretic analysis we found three different genotypes for $\kappa$-casein $\mathrm{AA}, \mathrm{AB}$ and $\mathrm{BB}$ (Figure 3).

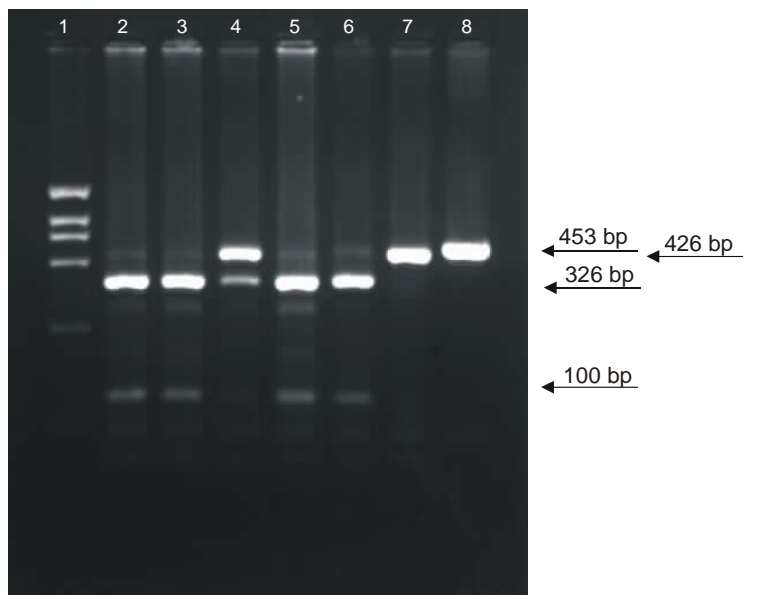

Figure 3. 1.5\% agarose gel electrophoresis of digested PCR products using Hinf I enzyme. In 1 DNA ladder, lns 2, 3, 5 and 6 AA genotype, ln 4 AB genotype; $\ln 7$ BB genotype, ln 8 undigested amplification.

The frequencies were $0.747: 0.253$ of the alleles A and B respectively, indicating dominancy of the A allele. Statistical analyses show that dairy cows with $\mathrm{BB}$ and $\mathrm{AB}$ genotype of $\kappa$-casein have $10 \%$ higher yield of milk than those with AA genotype. It was also shown that the duration of lactation was $12 \%$ longer in cows with the $\mathrm{BB}$ genotype compared with $\mathrm{AA}$ and $\mathrm{AB}$ genotypes. Milk yielded by cows with the $\mathrm{BB}$ genotype exhibited the shortest time for the initial and final coagulation in the process of cheese making which is $30 \%$ shorter in contrast with that of AA genotype. Milk yielded by cows with $\mathrm{AB}$ genotype showed an intermediate effect. During the cheese making process it was shown that syneresis was $14 \%$ higher in the $A B$ and $\mathrm{BB}$ genotypes in contrast to the AA genotype. Based on these data, in the future, dairy cows with the BB genotypes should be favored in the reproduction in order to gain higher yields of milk and cheese [23].

\section{Polymorphisms in ovine $\alpha s_{1}$-casein gene among autochthon strains of Pramenka breed sheep in the Balkans}

Alpha $S_{1}\left(\alpha S_{1)}\right.$ casein represents the main milk protein fraction which has an important role in 
the transport calcium phosphate in milk. There are four alleles (A, B, C and D) present in the $\alpha \mathrm{S}_{1}$ casein gene. In domesticated ruminants $\alpha S_{1}$ casein is polymorphic and the variants are related to the milk yield and quality [24]. Polymorphisms were detected within ovine $\alpha_{s 1}$-casein gene using PCR - RFLP [25]. One hundred seventeen DNA samples were isolated from 6 different strains of Pramenka sheep from different parts of the Balkan Peninsula: Karakachanka (Macedonia), Svrljiska (Serbia), Bardoka (Kosovo), Istarska (Croatia), Dubska (Bosnia and Herzegovina) and Pivska (Montenegro). Three distinct patterns (designated non $\mathrm{A} / \mathrm{non} \mathrm{A}$, nonA/A and A/A) were observed (Figure 4).

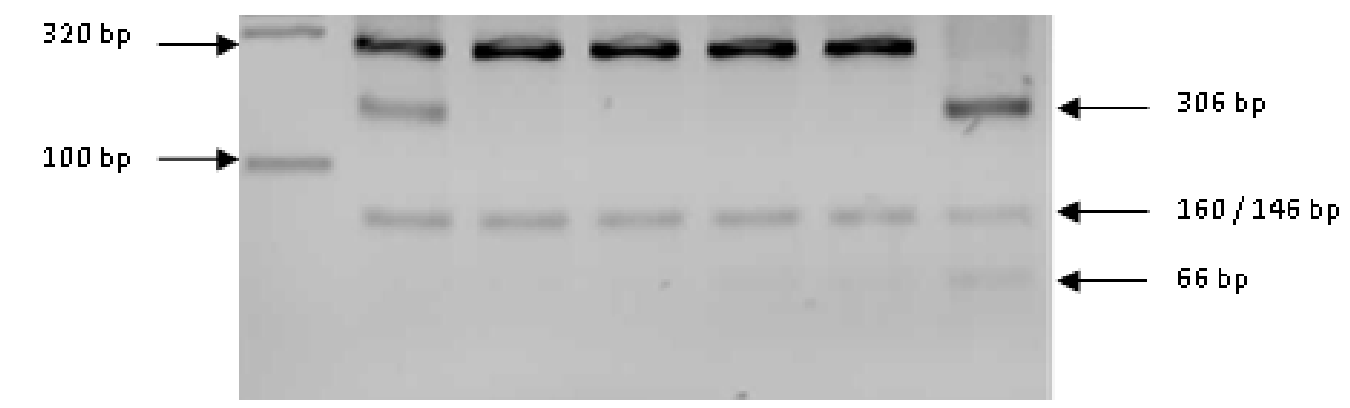

Figure 4. 3\% agarose gel electrophoresis of $M b o$ II digested PCR products: ln 1 - DNA ladder; $\ln 2$ - A/nonA, lns 3-6,- nonA/nonA; ln 7- A/A.

Allelic frequencies were 0.08/0.92 A/nonA. No polymorphisms were observed in Bardoka and Istarska strains and all animals carried the nonA/nonA genotype. The highest diversity, related to $\alpha S_{1}$ casein gene, were in the Karakachanka strain where 7 animals had nonA/A genotype, while 2 carried genotype A/A [26].

\section{Polymorphisms of hemoglobin in conserved nucleus of Karakachan sheep in Macedonia}

Karakachan sheep is an autochthonic and endangered strain of Pramenka breed in the southern part of the Balkan Peninsula was part of the program for the conservation of autochthonic breeds and strains of domestic animals. In the Republic of Macedonia, 60 Karakachan sheep were identified and conserved in situ. In 1966, Acad. Efremov discovered a new hemoglobin type in sheep [27]. The aim of this study was to determine the polymorphism of hemoglobin among those 60 animals using the established techniques by Acad. Efremov. $11 \%$ starch gel electrophoresis in TRIS-HCl buffer $\mathrm{pH} 8.3$ was used for the separation of different types of hemoglobin. Using this type of horizontal electrophoresis we found two different types of hemoglobin A and N (Figure 5).

The frequency of the allele $\mathrm{A}$ in this sheep population is 0.884 , while the frequency of the $\mathrm{N}$ allele of hemoglobin is 0.116 [28]. There are confirmed associations of the different types of hemoglobin with sheep milk quantity.

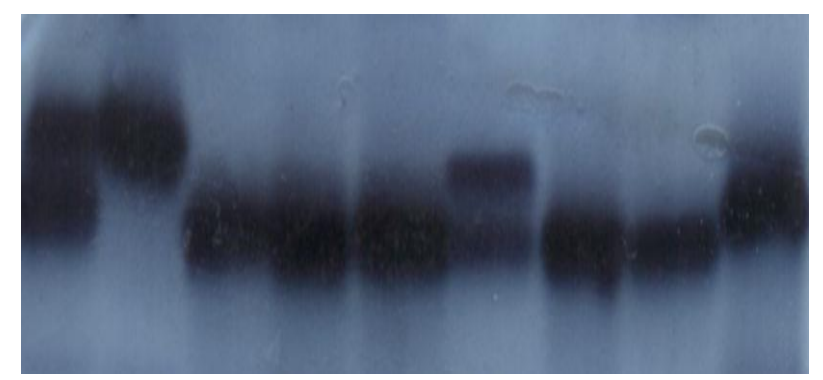

Figure 5.Starch gel electrophoresis of sheep hemoglobin: 1-genotype AX; 2-genotype XX;

3-5-genotype AA, 6-genotypy AX, 7-8 genotype AA, 9-human hemoglobin (control)

\section{Variability of microsatellite DNA among autochthonic strains of Pramenka breed}

The microsatellites known as simple sequence repeats (SSRs) are a novel class of DNA markers which are able to detect higher level of genetic variability. They are short tandem repeats (2-10 bp), middle repetitive, tandemly arranged, hypervariable DNA sequences dispersed throughout fungal, plant, animal and human genome [29]. SSRs have been used in population genetics, parentage testing, individual identification and for shortening breeding programs. Pramenka is the common name for all coarsewooled sheep breed in the Balkan mountains. There are many different phenotypical types of Pramenka, and some of them still have an important place in sheep breeding, especially in areas with rough climate conditions and poor pastures. The aims of this study were to esti- 
mate the applicability and degree of polymorphism of used DNA microsatellites loci in the genome of Sharplaninian, Ovchepolian and Karakachanian strains of Pramenka sheep breed; to determine the genetic distance and genetic diversity between sheep strains of Pramenka sheep breed in the Republic of Macedonia; to determine the genetic variability of individuals from the analyzed strains of Pramenka sheep breed as well asto construct the phylogenic tree of analyzed sheep strains of Pramenka sheep breed using Unrooted Neighborhood Joint Tree method. In this study 105 adult individuals from indigenous sheep breed, Pramen$\mathrm{ka}$, (35 individuals per population) were analyzed. To avoid sampling of closely related animals, collection was carried out on seven different sheep herds at different locations [30]. As a comparing breed was used the Sardinian one. The determined values for genetic distance and coefficients of genetic identity $(\mathrm{D}=0.381 ; \mathrm{I}=0.627$ ) have shown that the closest genomes are those of Sharplaninian and Ovchepolian sheep strains. The biggest differentiation $(\mathrm{D}=0.426 ; \mathrm{I}=0.606)$ is noted between genomes of Sharplaninian and Karakachanian sheep strains. The lowest similarity or highest distance $(\mathrm{D}=0.460 ; \mathrm{I}=0.578)$ is present between the genomes of Karakachanian and Ovchepolian strains. Values of genetic distance and genetic identity between Macedonian sheep breed strains and Sardinian sheep breed are due to the geographical distance and different production traits. Based on the values for genetic distance and coefficient of genetic identity, the degree of divergence between analyzed indigenous sheep populations can be determined. The introduction of herd book represents necessity for further controls of productive and reproductive characteristic in indigenous sheep populations. DNA microsatellites represent just a part of the total genomic DNA but because of their very useful properties they are widely used in animal population studies. Genetic diversity between indigenous sheep populations in the Republic of Macedonia and inside the populations in this study were determined trough the analysis of 15 DNA microsatellites (4 bovine loci, 5 goat loci and 6 sheep loci)[31] (Figure 6).
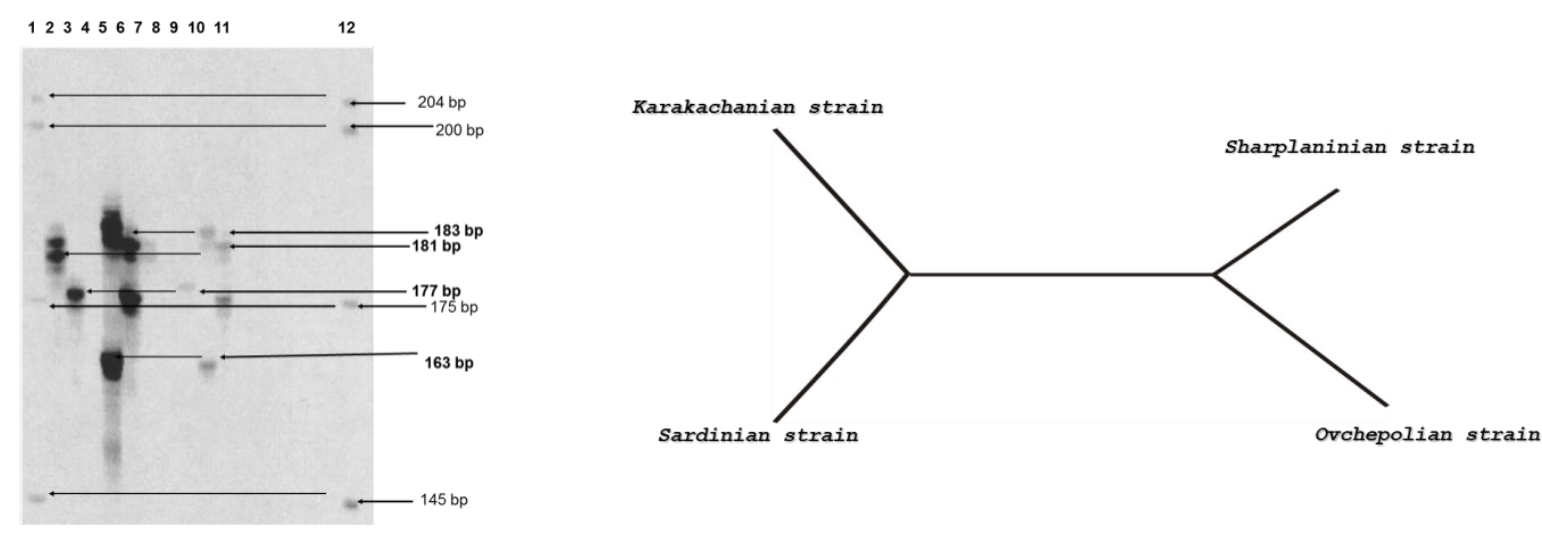

A)B)

Figure 6. Genetic distance between autochthonic strains of Pramenka breed in Macedonia. A) Fragment analysis of microsatellite DNA. B) Phylogenetic tree

\section{The influence of size and living temperatures on the muscle protein profile of Koi carp (Cyprinus carpio haematopterus)}

The fish muscle proteins can be divided into 3 groups: myofibrillar proteins - soluble in concentrated salt solutions (actin, myosin, actomyosin, tropomyosin etc.); sarcoplasmic proteins - soluble in water or soluble in diluted salt solutions (metabolic enzymes, globulin, myoglobin etc.); and connective tissue proteins - proteins insoluble in water or salt solutions like collagen [32]. Protein separation is commonly done using sodium dodecyl sul- fate polyacrylamide gel electrophoresis (SDSPAGE) which achieves separation predominantly based on the length of their polypeptide chains [33]. The goal of this study was to show the variations in the muscle protein gene expression in Koi carp (Cyprinus carpio haematopterus) caused by the fish size and living temperature differences. SDS-PAGE methodology, image and statistical analyses were used [34]. Samples from 24 different fish were analyzed, separated into two groups, large and small fish, raised in three different temperatures 5, 25 and $30^{\circ} \mathrm{C}$ (Figure 7). 


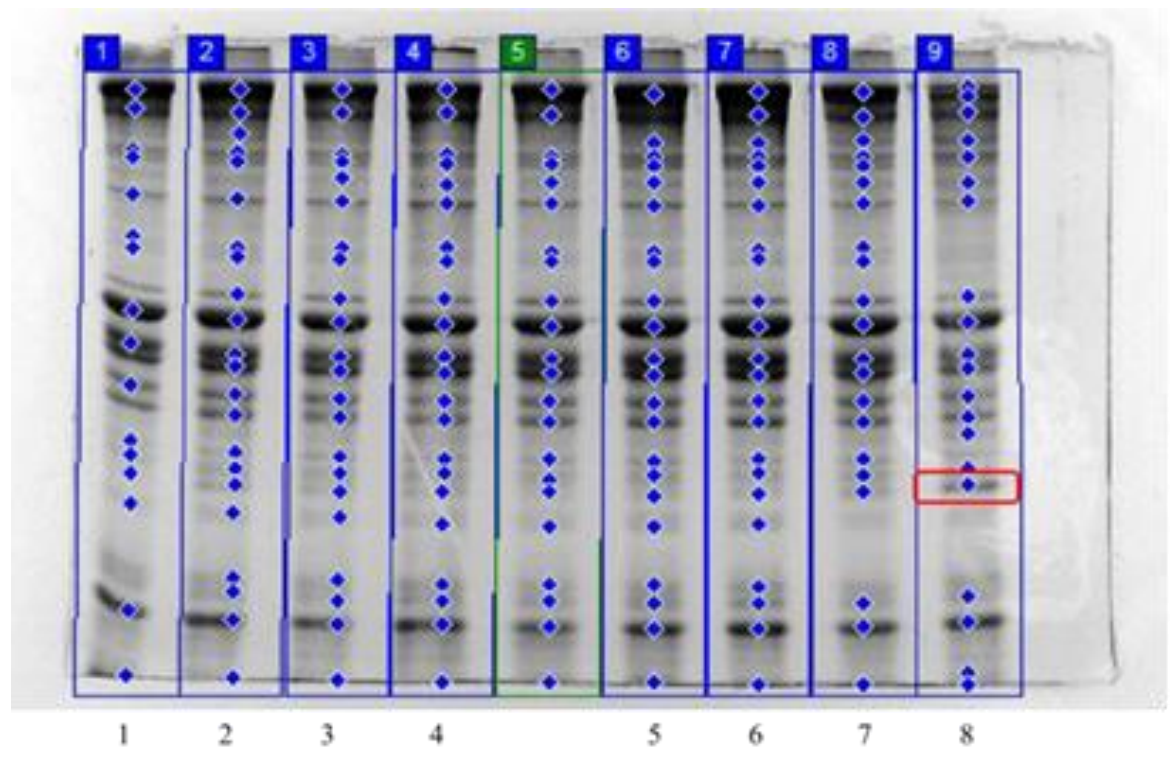

Figure 7. $10 \%$ SDS-PAGE analysis: samples 1, 2, 3 and 4 were prepared from small fish raised at $5{ }^{\circ} \mathrm{C}$; samples 5, 6, 7 and 8 were prepared from large fish raised at $5{ }^{\circ} \mathrm{C}$

The results showed concentration differences in proteins located at the same region in the gels, present in some of the large fish raised at temperatures of $5{ }^{\circ} \mathrm{C}$ and $25{ }^{\circ} \mathrm{C}$, which points to the possible influence of the fish size and living temperatures on the muscle protein profile of the Koi carp. These types of variations were not recognized in the remaining analyzed samples [35].

\section{Determination of RNA/DNA ratio in white muscle samples of Koi carp using different techniques}

The amount of DNA in a cell is constant; the amount of RNA indicates how actively the cell is synthesizing proteins, and thus perhaps an indication of the metabolic status of the organism in terms of growth [36]. DNA content remains relatively constant even during periods of starvation and can serve to normalize the measured RNA. RNA is the template for the translation the genetic code into the cell's metabolic and structural machinery. The amount of RNA fluctuates in response to multiple stimuli including food availability in the natural food habitats. When properly calibrated the RNA/DNA ratio (R/D) ratio can be used to estimate instantaneous growth rates. The R/D ratio is an indicator of muscle growth capacity in fish. Some studies have advocated caution in the use of the $\mathrm{R} / \mathrm{D}$ ratio because of the lack of sensitivity. In this study we estimated the R/D ratios in 24 samples of Koi carp divided in 2 groups (small and large size) and three temperature subgroups $5{ }^{\circ} \mathrm{C}, 25{ }^{\circ} \mathrm{C}$ and 30 ${ }^{\circ} \mathrm{C}$. All fish were grown under the same feeding conditions for 6 weeks. Modified TRIzolTM method for simultaneous isolation of RNA and DNA was used according to the manufacturer's recommendation to isolate and purify RNA and DNA (Figure 8).

The results showed that the average values for the R/D ratio in large fish adapted to $25^{\circ} \mathrm{C}$ was the highest (4.23), while the difference was shown in the samples from fish adapted to $5{ }^{\circ} \mathrm{C}$ and $30^{\circ} \mathrm{C}$. The results obtained using the TRIzol ${ }^{\mathrm{TM}}$ method are consistent with the literature [37] and showed that the fish adapted to $5{ }^{\circ} \mathrm{C}$ had a higher R/D ratio compared with those from the fish adapted to $30{ }^{\circ} \mathrm{C}$ $(\mathrm{P}=0.027)$ (Figure 9).

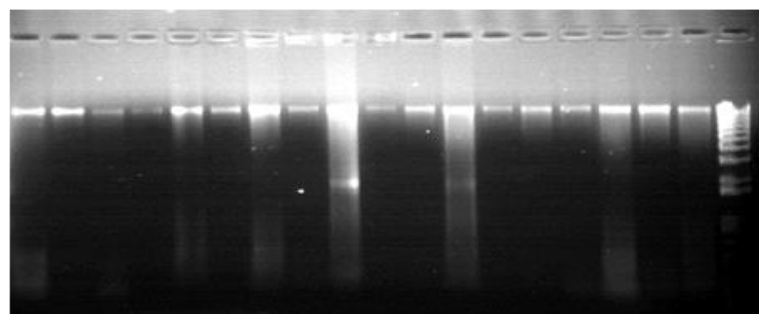

Figure 8. $0.9 \%$ agarose gel electrophoresis of RNA and DNA simultaneous isolates using the TRIzol ${ }^{\mathrm{TM}}$ method 


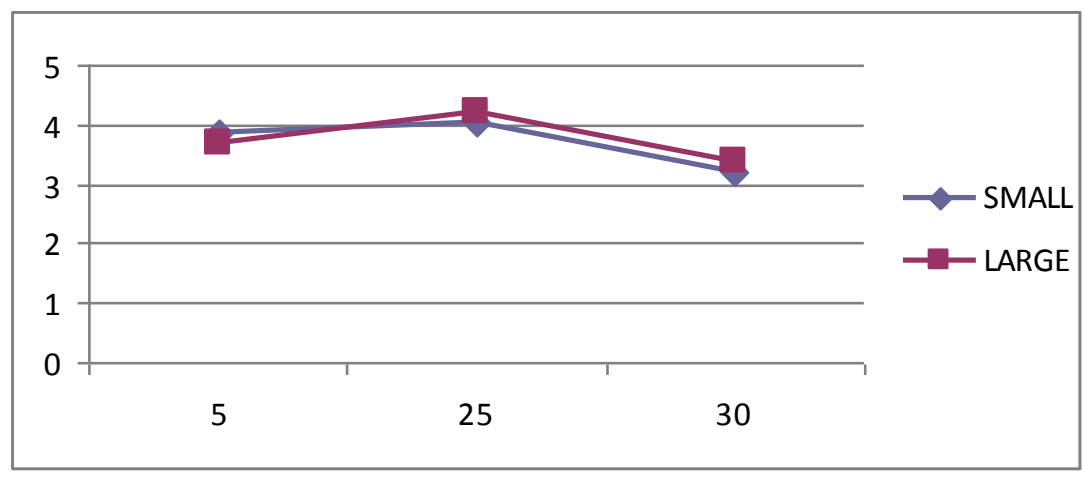

Figure 9.Average values of R/D ratios among different groups of fish grown at different temperatures determined using $\mathrm{TRIzol}^{\mathrm{TM}}$ technique

\section{Electrophoretic determination of a female specific protein in Koi carp as a tool for gender identification}

Numerous studies have demonstrated the impact of proteomics on answering key biological questions; especially those that help us understand vital functions of a living system [38]. Plasma proteins are a suitable proxy for the physiological sta- tus in the organism. Gender identification among fish species, based on morphological features, is very difficult and therefore the electrophoresis of plasma proteins could be simple and reliable tool. In this study, sodium dodecyl sulfate-polyacrylamide gel electrophoresis (SDS-PAGE), combined with image analysis, was used to analyze plasma proteins of Koi carp Cyprinus carpio haematopterus (Figure 10).

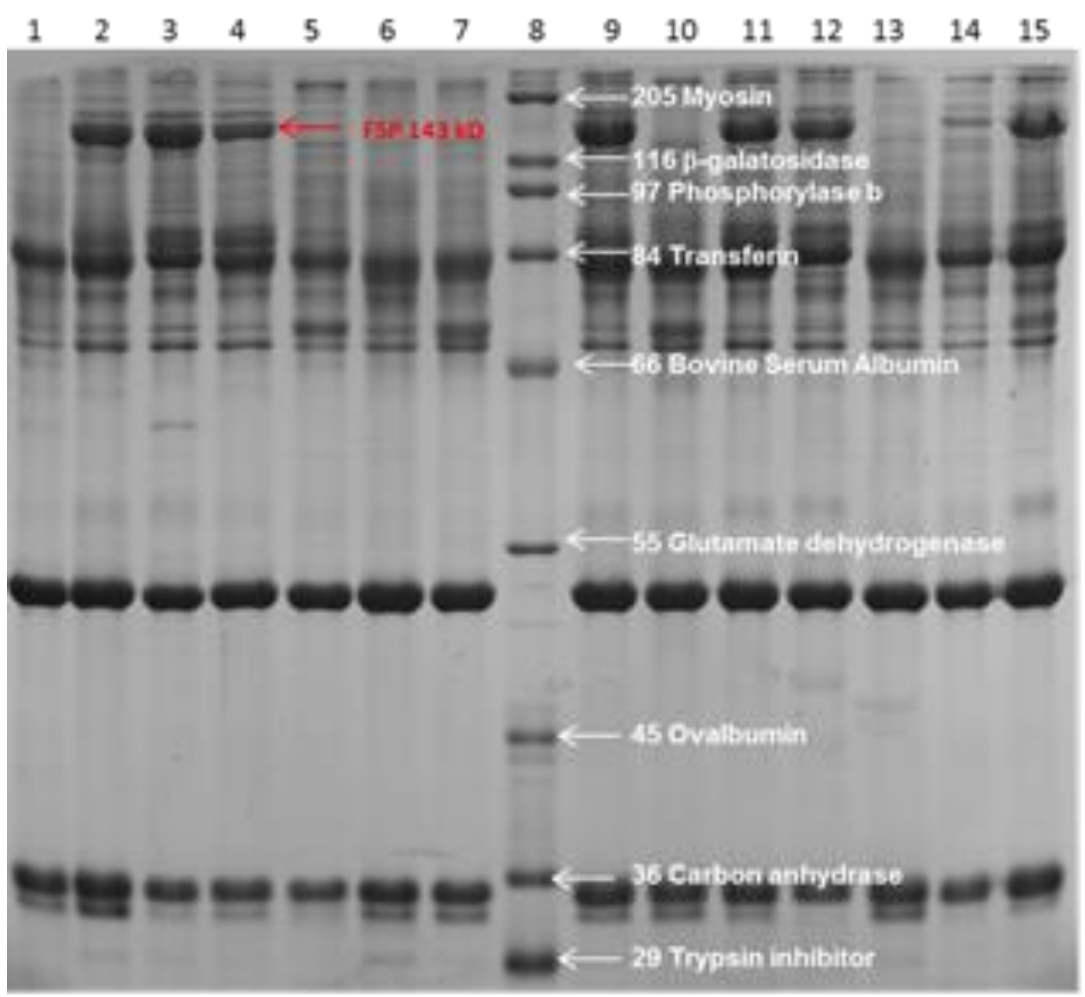

Figure 10. 12.5\% SDS-PAGE on plasma proteins from 14 samples of Koi carp.

1, 5, 6, 7, 10, 13 and 14 males / 2, 3, 4, 9, 11, 12, 15 females; 8 Broad Range Standard (myosin $205 \mathrm{kD}$, galatosidase 116 $\mathrm{kD}$, phosphorilase b $97 \mathrm{kD}$, transferrin $84 \mathrm{kD}$, bovine plasma albumin $66 \mathrm{kD}$, glutamate dehydrogenase $55 \mathrm{kD}$, ovalbumin $45 \mathrm{kD}$, carbon anhydrase $36 \mathrm{kD}$ and trypsin inhibitor $29 \mathrm{kD}$ ) 
The electropherograms showed that using SDS-PAGE is a simple and reliable tool to discriminate male from female samples based on the presence of female specific protein (FSP). This protein, therefore, can be used as a suitable marker. The molecular weight of FSP is approximately $200 \mathrm{kDa}$ and is consistent with pervious findings from the studies of different fish species [39].

\section{Achievements in crop science}

The targeted crops in our studies were tomato and pepper because they are the most important vegetables in production in the Republic of Macedonia. The tomato was investigated at both the protein and DNA levels in order to determine the genetic distance between six tomato varieties conserved in a National Gene Bank at the Institute of Agriculture. The pepper was analyzed from the phyto-pathological point of view to identify and characterize cucumber mosaic virus (CMV), alfaalfa mosaic virus (AAMV) and potato virus $\mathrm{Y}$ (PVY) as most frequent viruses.

\section{Differences in tomato seed protein profiles obtained by SDS-PAGE analysis}

The use of proteins as markers hasbeen shown to have wide application in the identification and estimation of plant quality characteristics, disease resistance and environmental stress conditions. Seed storage protein analysis is very useful for differentiating and characterizing ecotypes. Endosperm seed protein analysis constitutes a valid and/or improved approach to cultivar identification, which is commonly based on morphological traits recorded in the field [40]. Storage proteins, as direct gene products, are currently used as genetic markers in parallel with morphological characteristics [41].The protein profiles of tomato seeds from sub-species (subsp. cultum Brezh., subsp. subspontaneum Brezh. and subsp. spontaneum Brezh.) were analyzed using SDS-PAGE. Electropherograms and densitograms of total, soluble and non-soluble proteins of 31 different samples showed quantitative and qualitative differences (Figure 11).

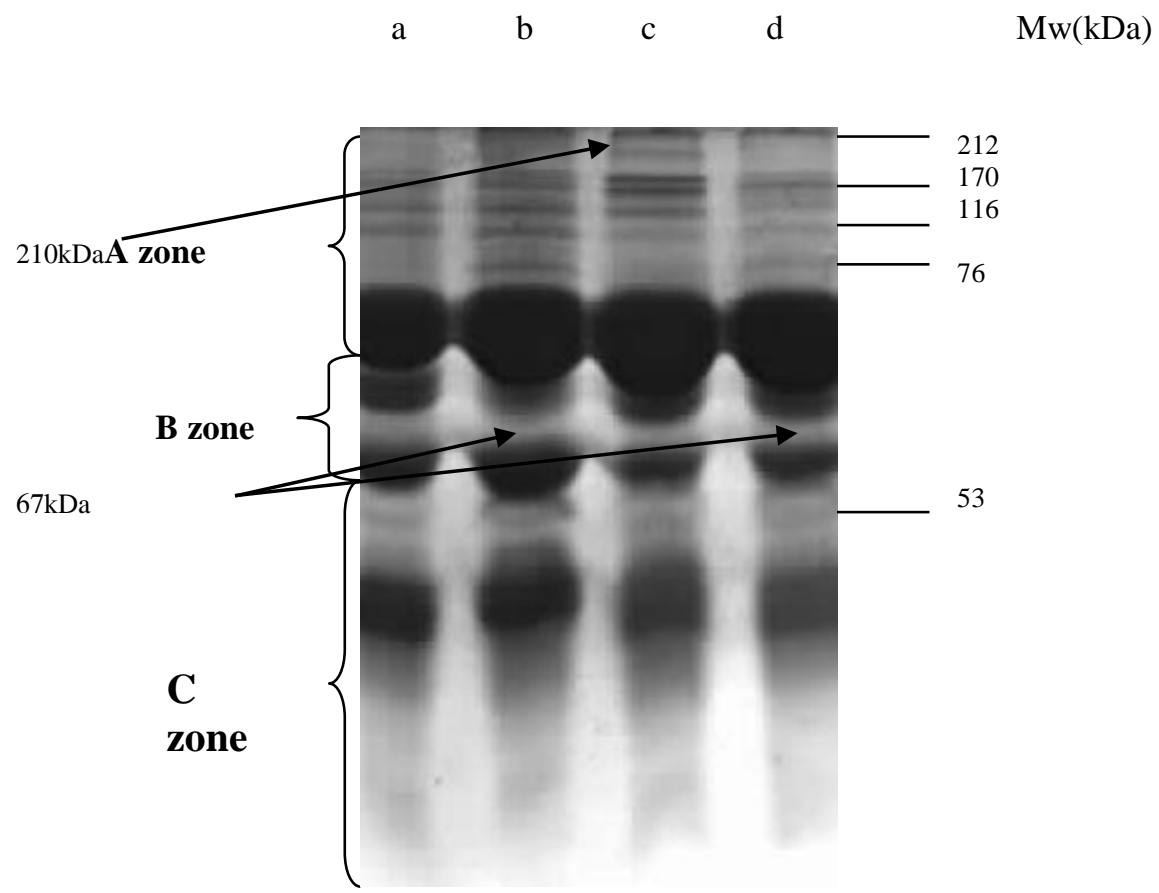

Figure 11. SDS-PAGE electropherogramsof non-soluble tomato seed proteinsa - population Volovskosrce; b- line 12 mercedes; c-hybrid 677; d-hybrid 312

Qualitative differences in electropherograms of total seed proteins refer to protein fragments in zone A (114 kDa, $83 \mathrm{kDa}$ and $65 \mathrm{kDa})$ and protein fragments in zone C (17 kDa). Qualitative differences in electropherogramsof soluble seed proteins refer to protein fragment in zone A (94 $\mathrm{kDa}$ ). Qualitative differences in electropherogramsof non-soluble seed proteins refer to protein fragments with molecular weights: $212 \mathrm{kDa}, 17085$ $\mathrm{kDa}, 116 \mathrm{kDa} 76$ and $53 \mathrm{kDa}$ [42]. 


\section{Study of DNA microsatellites in different tomato varieties}

The microsatellites, also called simple sequence repeats (SSRs) appear as suitable molecular markers because of their highly polymorphic character. The informativeness of microsatellites, as a genetic marker has been shown to have great success in several plant species [43]. The aim of this study was research of applicability of 12 DNA microsatellites loci in genetic characterization of 6 tomato varieties of Lycopersicon esculentum Mill.: var. grandifolium from subsp. cultum; var. cerasiforme (red and yellow), var. pruniforme and var. pyriformefrom subsp. subspontaneum; and var. racemigerum from subsp. spontaneum. The data was analyzed using the specific programs: such as POWER MARKER SOFTWARE and MEGA3. In the investigated tomato varieties, the biggest number of alleles (6) was detected at locus LEEF1Aa and locus LE20592, and only one allele was detected at locus LECHSOD by using of fragment analyses shown in Figure 12 [44, 45].

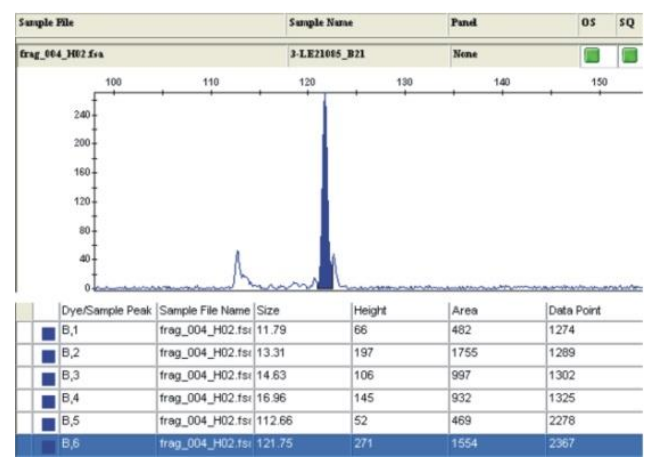

Figure 12. A) $2 \%$ agarose gel electrophoreses of PCR products for LE21085 locus in different tomato DNA: 1 - 12 - PCR products; 13 - DNA ladder, B)Electropherogramsof locus LE21085

For all microsatellites loci in the investigated tomato varieties, the average number of detected alleles was (3.6250). Average PIC value for all the 8 DNA microsatellites loci was (0.3571) and they belong to the group of modest informative markers. Based on microsatellites loci research, analysis of variance (AMOVA) showed that $25 \%$ of the total variance in investigated varieties was between varieties and $74.7 \%$ of the total variance in investigated varieties was within the varieties. The results of genetic distance showed slight genetic distance (16.7415) between Lycopersicon esculentum subsp. subspontaneum var. cerasiforme (yellow) and Lycopersicon esculentum subsp. subspontaneum var. cerasiforme (red), and the biggest genetic distance (34.9859) was noticed between Lycopersicon esculentum subsp. subspontaneum var. pyriforme and Lycopersicon esculentum subsp. cultum var. grandifolium. The results of determination of genetic distance [46], showed that the smallest genetic distance (22.1446) was noticed between Lycopersicon esculentum subsp. subspontaneum and Lycopersicon esculentum subsp. spontaneum, and the biggest genetic distance (19.7147) was noticed between Lycopersicon esculentum subsp. subspontaneum and Lycopersicon esculentum subsp. cultum [47]. Based on the statistical data a precise dendrogram was created (Figure 13).

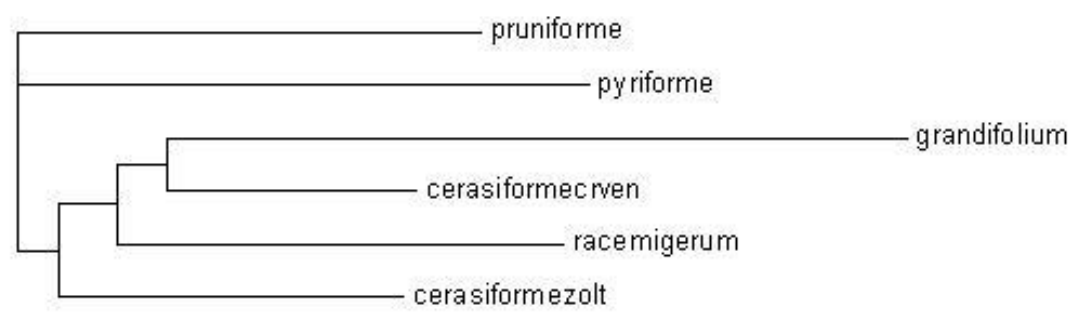

Figure 13. Dendrogram of analysed tomato varieties based on the genetic distance[47] 


\section{Molecular characterizationofCMV, AAMVandPVYon peppercultivated on open fieldsinthe Republic ofMacedonia}

Pepper viruses are the main limiting factor in the pepper production on open fields in the Republic of Macedonia. By determining the nucleotide sequences of the CP-gene, the isolates have been clustered in various groups by different authors [48]. The aim of this study was to determine the presence and spread of Cucumber mosaic virus CMV, Alfalfa mosaic virus - AAMV and Potato virus $\mathrm{Y}-\mathrm{PVY}$, the time of virus appearance, the dynamics of virus infection, the presence of mixed infections, as well as virus isolation and molecular characterization on peppers produced on open fields in the Republic of Macedonia. The data in this study are gained during the research that was conducted throughout the three vegetations in eight regions in the Republic of Macedonia on pepper plants produced on open fields. After the three year trial, it was determined that pepper plants produced on open fields are extremely susceptible to viral infections. During the analyzed years, cucumber mosaic virus was the most dominant virus, in some cases causing a $100 \%$ infection. Molecular characterization of the cucumber mosaic virus sequences is shown in Figures 14 and 15.
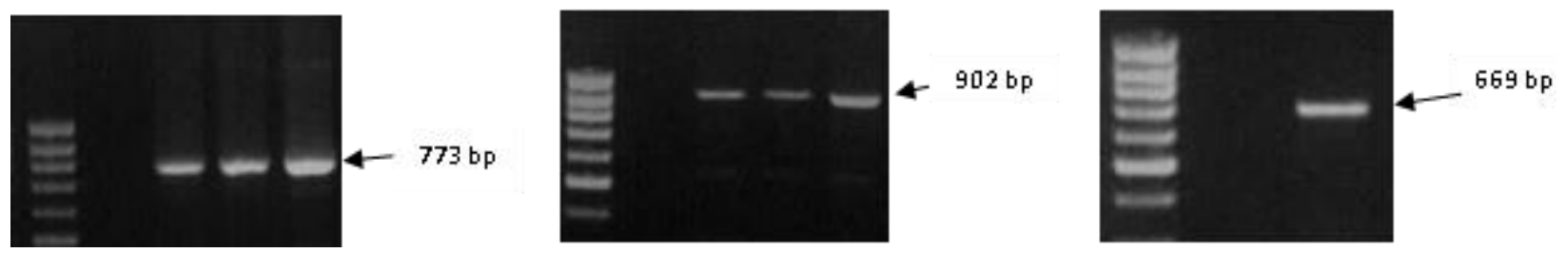

Figure 14. Agarose gel electrophoresis of amplicons from CMV, AMV, and PVY
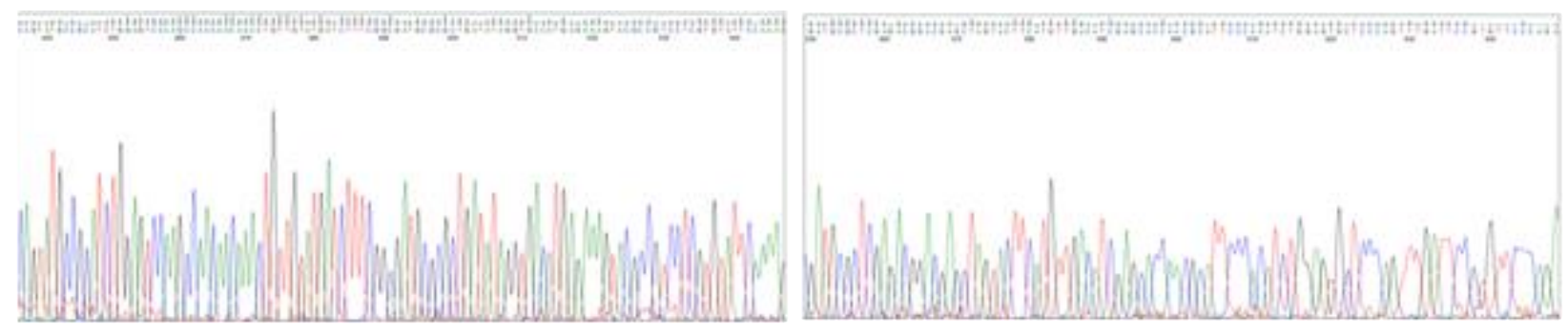

Figure 15.Nucleotide sequence of CMV2 isolate (582 bp) gained on Genetic Analyzer 3500, Applied Biosystems

Based on these data was determined that the CMV isolates from the Republic of Macedonia belong to the IA subgroup which is shown in the dendrogram (Figure16). After the analysis of potato virus $\mathrm{Y}$ sequences, it was established that isolates from the Republic of Macedonia are clustered in
PVYpep group, together with the other European PVY pepper isolates from the Mediterranean countries. After the molecular characterization of the alfalfa mosaic virus, it was determined that the AAMV isolate from the Republic of Macedonia belongs to the II group [49]. 


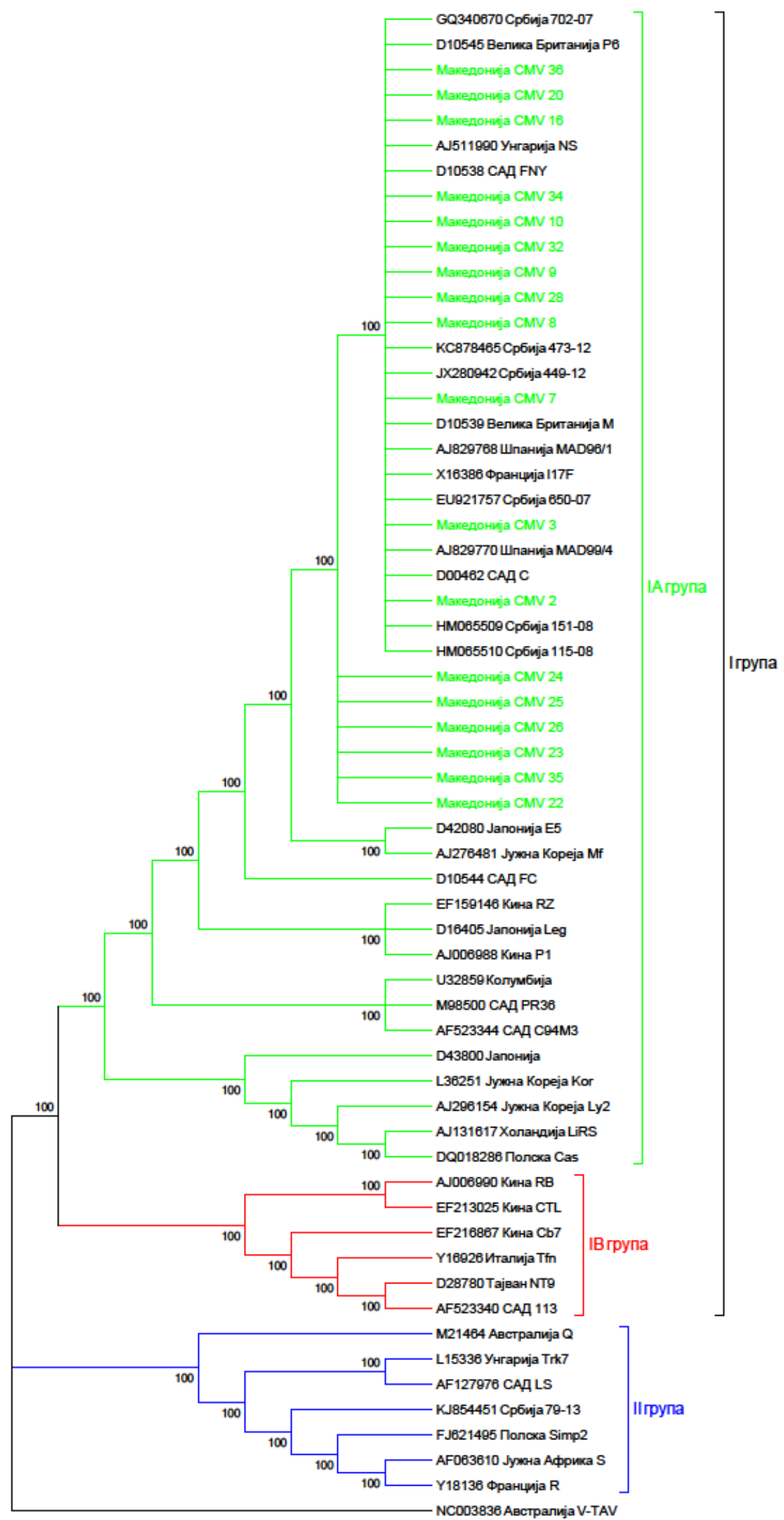

Figure 16. Dendrogram based on the differences in the sequence of core protein gene in CMV 


\section{Achievements in food control}

Food control is a sector which cannot be imagined without systematic application of molecular methods. Currently, there are several commercialized kits for detection and quantification of different ingredients or contaminants in the food based on the molecular approach. Since 2006, the GMO lab has been authorized for GMO control in the country by applying available methods developed and widened by the European Network of GMO Laboratories (ENGL) and European Union Reference Laboratory for Food and Feed Analysis. Beside, the routine application of validated methods for GMO control, there were also some screening procedures innovated as well as checking the level of sensitivity and specificity of some "in-house" techniques [50]. Beside the innovations in GMO control, procedures for investigation of the origin of dairy and meat products, and purity of chymosin as a main enzyme in milk processing were developed.

\section{Different approaches in GMO detection and semiquantification using CP4 EPSPS protein in GM corn}

All testing methodologies currently available for GMOs testing are based to detect either the novel DNA or the novel protein. Both protein and DNA-based methods have been developed and applied for detection of transgenic crops, and their derivatives. Protein based techniques are referred to as immunological techniques because the detection is based on the immunological principle of conjugation between an antigen (the target) and an antibody [51].In this study are presented the findings using different approaches in GMO detection in food samples on a protein level. As a starting material we have used corn GM seed NK603 with different concentrations of GMO provided from ISTA in the frame of proficiency testing. On the protein level we use dip sticks as qualitative and ELISA as a semiquantitative method where the target molecule was CP4 EPSPS enzyme. The results showed that dip sticks could detect the presence of $0,6 \%$ GMO (Figure 17).
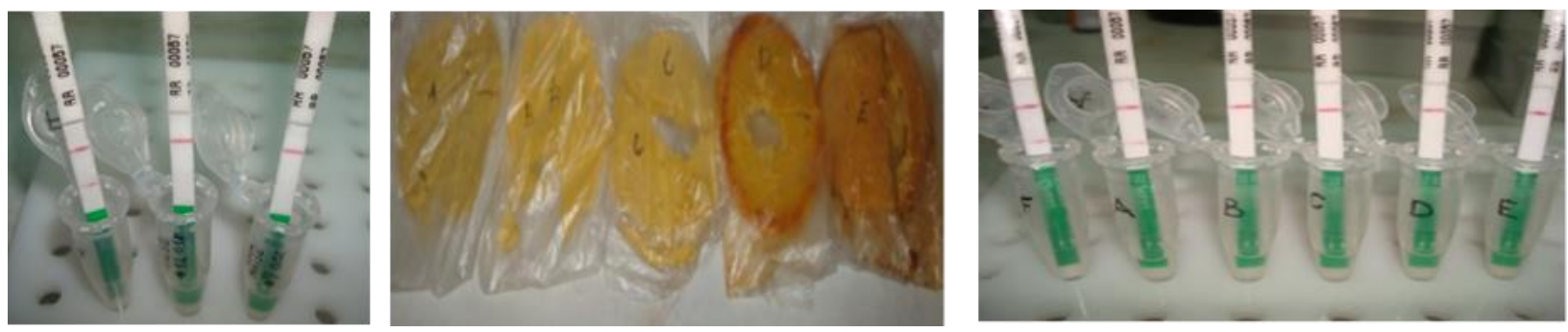

Figure 17. Determination of LOD on GM corn NK603.A) $0.6 \%$, B) $0.1 \%$ and C) $0.0 \%$. II. Paste prepared from $0.6 \%$ NK603 sample and baked at: (A) $50{ }^{\circ} \mathrm{C}$, (B) $100{ }^{\circ} \mathrm{C}$, (C) $150{ }^{\circ} \mathrm{C}$, (D) $200{ }^{\circ} \mathrm{C}$ and (E) $250{ }^{\circ} \mathrm{C}$.

ELISA method could reveal GM corn with concentration of $0,1 \%$ with the restriction for exact and precise quantification.. Beside the analysis of sensitivity level in a raw material in terms of con- centration, we also analyzed, at the protein level, the influence of temperature on the targeted protein for GMO detection in thermally treated corn flour (Figure 18).

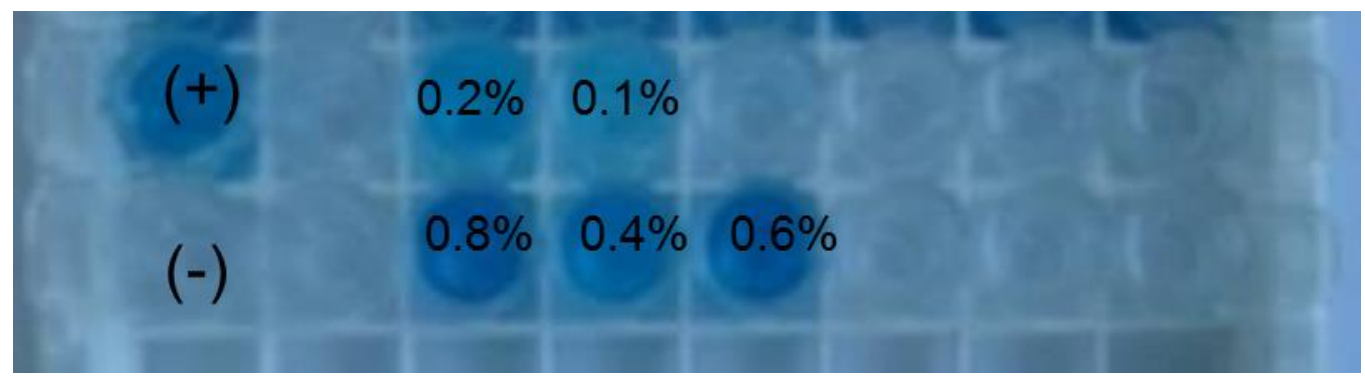

Figure 18.ELISA assay on GM corn samples NK603.with concentration of $0.1 \%, 0.2 \%, 0.4 \%, 0.6 \%$ and $0.8 \%$ 
In this case it was found that the last signal among the thermally treated samples using dip sticks with lowest signal was appearing at $80{ }^{\circ} \mathrm{C}$ [52].

\section{Detection and quantification of GMO at the DNA level}

Because the nucleotide sequence of GMOs is well known, the detection is done effectively using PCR. In order to reduce the costs in this study we did the screening of raw soy and some food products that contain soy in a single step with duplex PCR [53]. This study reports the screening of raw soy and some products that contain soy in a single step using duplex PCR. In the past, the screening had to be performed in two steps, one for revealing the soy DNA, and the second for detecting the presence of the construct that is present in GM soy. Optimization of the PCR conditions was performed focusing on $\mathrm{MgCl}_{2}$ concentration and primers annealing temperature. The data showed that a concentration of $3.0 \mathrm{mM} \mathrm{MgCl} 2$ and temperature of 60 ${ }^{\circ} \mathrm{C}$ were optimal to amplify both fragments in a single reaction. The results did not show any false positive or false negative data. They were wellmatched with those from the separately performed reactions (Figure 19).

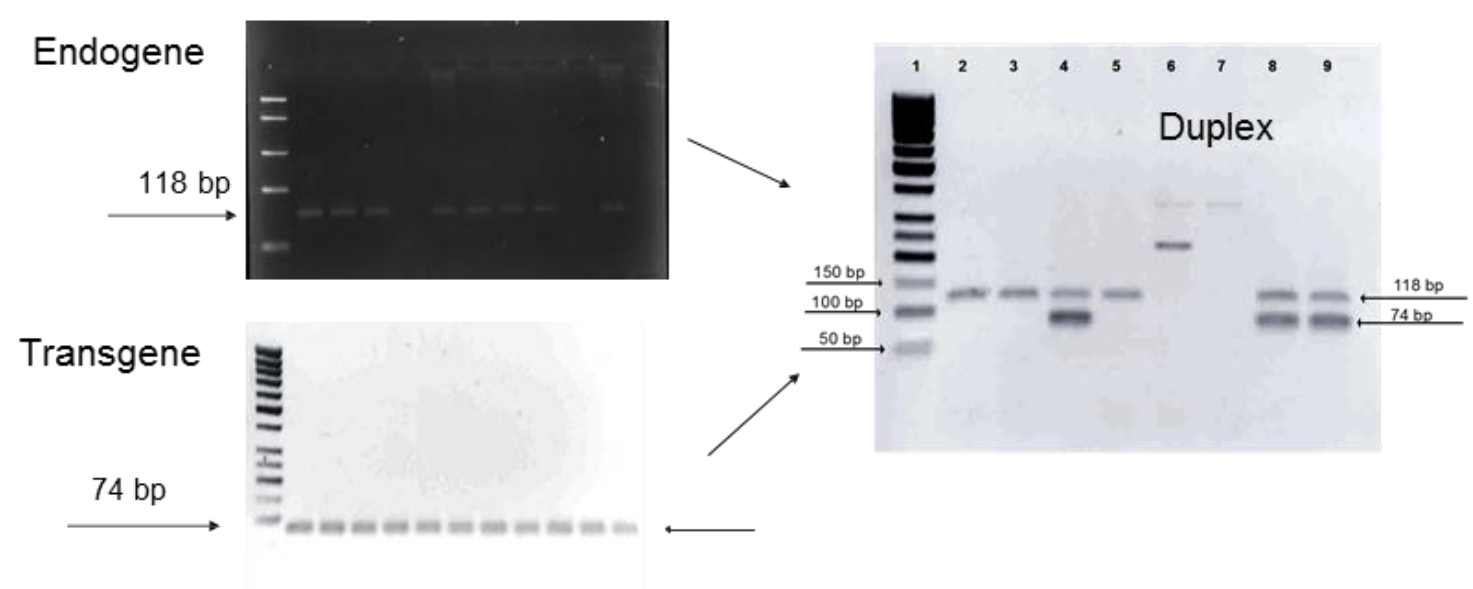

Figure 19. Electropherogram of duplex PCR: 1 - 50 bp ladder; 2, 3 soybeans, 4 positive control, 5 negative control, 6 soy milk (nonspecific amplification), 7 blank, 8, 9 chicken sausage

This kind of duplexed PCR enable faster detection of the presence of GM-soy. The method is shorter and cheaper [53]. This method eliminates so many negative samples before the quantification step with real-time PCR showed as shown in Figure 20.
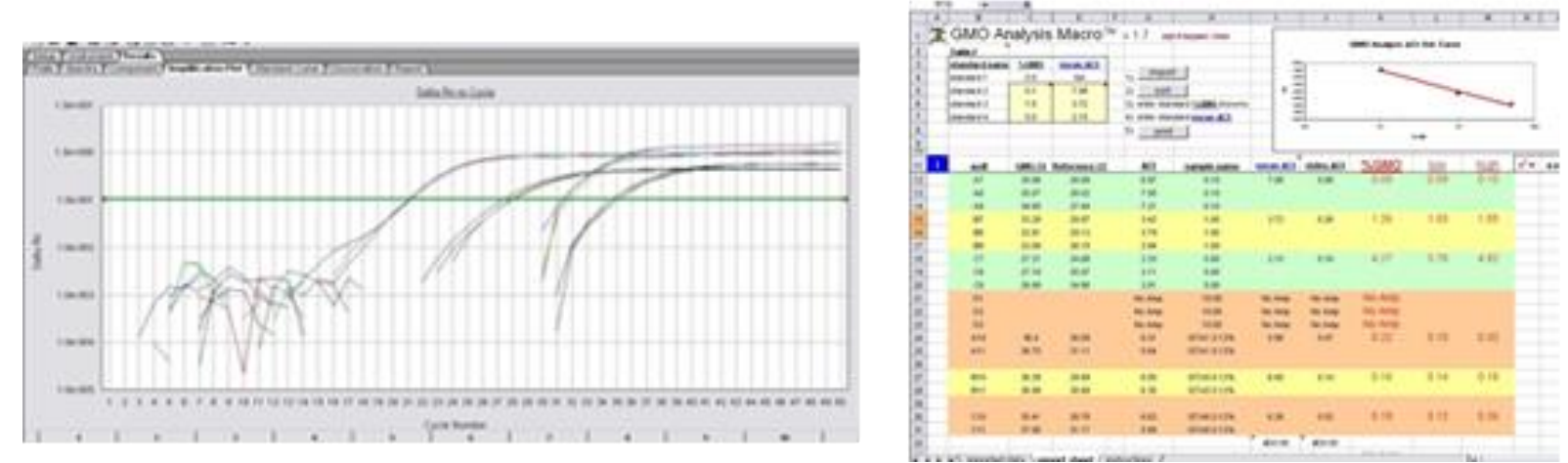

Figure 20. Real Time PCR quantification of GM corn during the proficiency testing 


\section{Rapid electrophoretic tool for origin identifica- tion of the different dairy products}

The major milk proteins are caseins, lactoalbumin, and lacto-globulin. These globular proteins are significant indicators of the milk and dairy products quality. Caseins, lacto-albumins and lactoglobulins vary in molecular weight and concentration in different types of milk. These differences can be used for determination of milk origin. The aim of this study was to develop an appropriate method for discriminating proteins from different origins. Twelve samples of milk, white cheese, yellow cheese and curd from dairy cattle, sheep and goats were collected and analyzed (Figure 21).

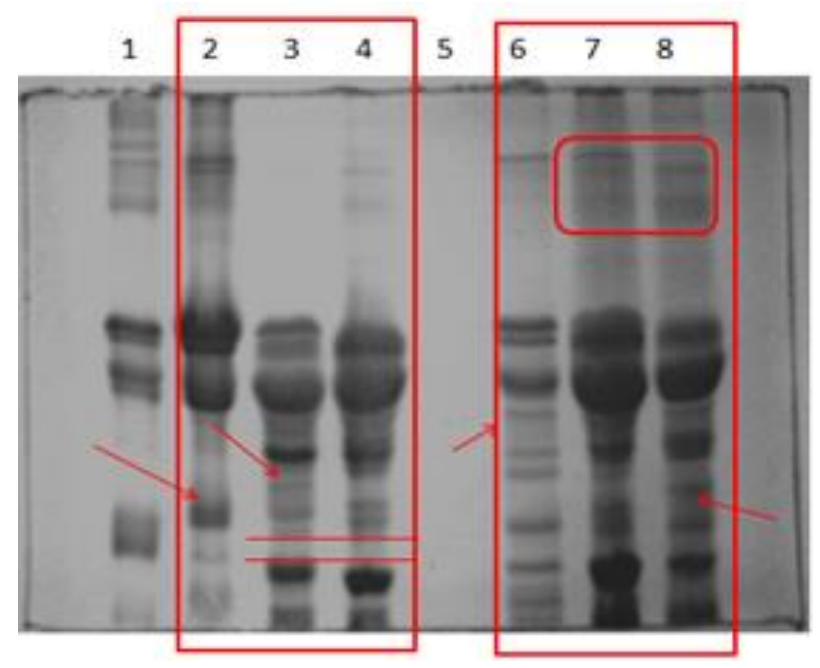

Figure 21. 15\% SDS-PAGE: 1.Milk standards-mix, 2. Cow yellow cheese, 3.Goat yellow cheese, 4 . Sheep yellow cheese, 5. /, 6. Cow white cheese, 7. Goat white cheese, 8. Sheep white cheese

The molecular weights of the proteins were determined using protein standards. The results showed differences, as well as the presence other fractions that can be used for identification of the origin [54].

\section{Different approaches in identification of the meat origin based on the protein profiling}

Meat origin is a fundamental factor impacting the quality and the usage of the meat products. Currently, modern kits for identification of the meat origin are available [55], however they are relatively expensive. This study developed a simple inexpensive technique that can be used in teaching purposes and in production management. We used SDS-PAGE for the identification of meat origin based on a given protein level and validated using simple PCR for amplification of part of RYR1 gene. [15]. The SDS-PAGE method previously optimized by changing the running conditions, amount of loaded sample materials and the concentration of the gel itself, has shown that different types of meat could be distinguished (Figure 22).

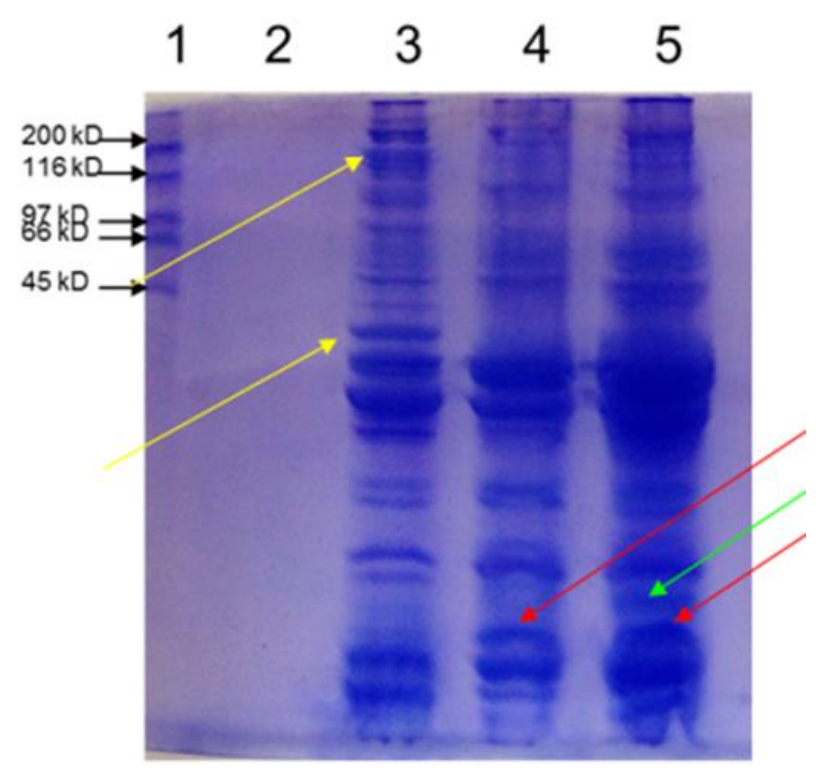

Figure 22. Differentiation of meat origin using $15 \%$ SDS PAGE of meat proteins: 1 protein standards; 2 empty; 3 chicken meat; 4 pork meat; 5 beef meat

The differences in protein profile of poultry meat were observed compared to the other samples where two specific fractions between 116 and 200 $\mathrm{kDa}$ are identified in the zone of myosin heavy chains and one below $45 \mathrm{kDa}$ in the zone of actin. In the beef samples there is a specific fraction in the zone of tropomyosin, while in pork and beef samples a fraction appears in the zone of myosin light chains [56].

\section{Development of a protocol for analyzing chymosin purity}

Chymosin, aspartic endopeptidases (EC 3.4.23.4) is a proteolytic enzyme found in rennet, and is the key enzyme in cheese production [57]. The aim of this study was to determine the purity of different commercially available chymosins and its equivalents using electrophoretic and chromatographic techniques. Chymosins produced by the company Chr. Hansen, CHY-MAX 200 and CHYMAX Plus, CHY-MAX PowderExtra NB as well as Maxiren 1800 Granulate from the company DSM, Sirnik from SZR - Travnik, Kraljevo and Planika from Mikroprocessing, Bileca were used in this 
study. The purity level of the commercially available enzymes was analyzed using SDS-PAGE (Figure 23).

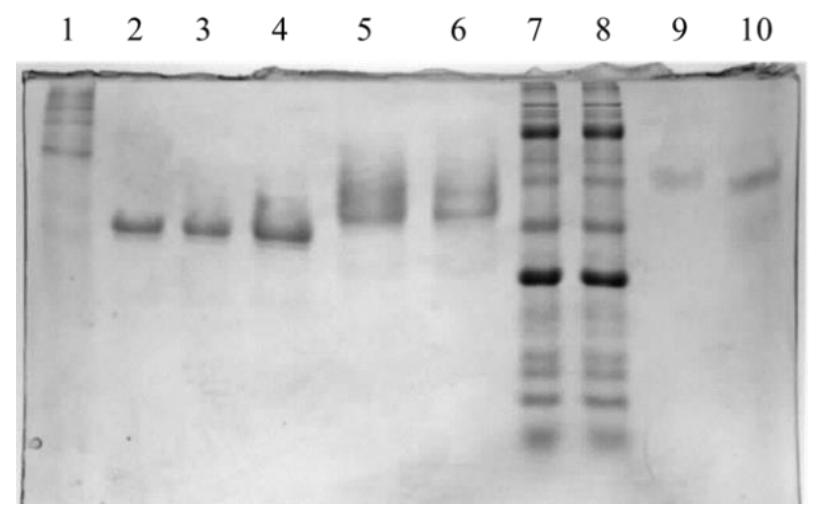

Figure 23. 12,5 \% SDS-PAGE analysis: 1 - High range protein standard 2,5 $\mu \mathrm{l} ; 2$ - CHY-MAX PowderExtra NB 5 $\% 15 \mu \mathrm{l} ; 3$ - Maxiren1800 Granulate $5 \% 15 \mu \mathrm{l} ; 4$-CHYMAX Plus $15 \mu \mathrm{l} ; 5$-CHY-MAX M $20015 \mu \mathrm{l} ; 6$ - CHYMAX M $20010 \mu \mathrm{l} ; 7$-Full range protein standard 2,5 $\mu \mathrm{l}$; 8 -Full range protein standard $2,5 \mu \mathrm{l} ; 9$-Sirnik $15 \mu \mathrm{l}$; 10- Planika $15 \mu \mathrm{l}$

Results showed no presence of undeclared protein fractions in the samples except for $\mathrm{CHY}$ MAX M 200 which had two protein fractions, most likely as a result of a polymorphism. All the CHYMAX and Maxiren samples have chymosin as the active component (36 kDa), except for Planika and Sirnik which have a natural protease from $R$. miehei [58].

\section{FUTURE PERSPECTIVES}

Presented achievements in application of contemporary molecular tools in livestock, agriculture and food processing sector in the Republic of Macedonia showed that the country posses human potential and technical capacities for widening of this methods on the routine basis. It should be recognized as non-replaceable factor which can increase the productivity, the efficiency of food control and rational use of natural and climate conditions and genetic resources. Most of those outcomes are gained in the frame of international projects, so currently is important to provide national contribution from the budget of the ministries closely related to this field.

\section{REFERENCES}

[1] Current applications of biotechnology, Editor in Chief Munis Dündar, Fabrizio Bruschi, KevanGartland, Mariapia, Viola Magni, Peter Gahan,
Yusuf Deeni, European Biotechnology Thematic Network Association, 2013.

[2] J. L. Williams: The use of marker-assisted selection in animal breeding and biotechnology, Rev. sci. tech. Off. int. Epiz., 24 (1) (2005), pp. 379391.

[3] J. Franco, J. Crossa, J. M. Ribaut, J. Betran, M. L. Warburton, M. Khairallah, A method for combining molecular markers and phenotypic attributes for classifying plant genotypes, Theor. Appl. Genet, 103 (6-7) (2001), pp. 944-952.

[4] J. C. M. Dekkers: Commercial application of marker and gene assisted selection in livestock: strategies and lessons, J. Anim. Sci., 82 (2004), pp. 313-328.

[5] R. Djedović, G. Trifunović, D. Stanojević: Genomic Selection. Proceedings of the First International Symposium on Animal Science. Belgrade, Serbia. Book I, (2012), pp. 207-216.

[6] C. He, V. Poysa, K. Yu, Development and characterization of simple sequence repeat (SSR) markers and their use in determining relationship among Lycopersicum esculentum cultivars, Theor. Appl. Genet., 10 (2003), pp. 363-373.

[7] Y. Jiao, H. Jia, X. Li, M. Chai, H. Jia, Development of simple sequence repeat (SSR) markers from a genome survey of Chinese bayberry (Myricarubra), BMC Genomics, 13 (2012), pp.1-16.

[8] L. Herrera-Estrella, A. Depicker, M. van Montagu, J. Schell, Expression of chimaeric genes transferred into plant cells using a Ti-plasmid-derived vector, Nature, 303 (1983), pp. 209-213.

[9] J. Zel, M. Mazzara, C. Savini, S. Cordeil, M. Camloh, D. Štebih, K. Cankar, K. Gruden, D. Morisset, G. Van den Eede: Method validation and quality management in the flexible scope of accreditation: An example of laboratories testing for genetically modified organisms, Food Anal. Meth., (1), Issue 2, (2008), pp. 61-72.

[10] W. Dong, L. Yang, K. Shen, B. Kim, G.A. Kleter, J. P. Marvin, H. R. Guo, W. Liang, D. Zhang, GMDD: A database of GMO detection methods, BMC Bioinformatics, 9 (2008): 260.

[11] P. Zachar. Identification of milk and milk products, Mljekarstvo61 (3) (2011), pp. 199-207.

[12] K. Mullis, F. Faloona, S. Scharf, R. Saiki, G. Horn, H. Erlich: Specific enzymatic amplification of DNA in vitro. Polymerase chain reaction. Cold Spring Harbor, Symp. Quant. Biology, (1986), pp. $51-263$.

[13] J. Fujii, K. Otsu, F. Zorzato, S. de Leon, V. K. Khanna, J. E. Weiler, P. J. O'Brien, D. H. MacLennan: Identification of a mutation in Porcine Ryanodine Receptor Associated with Malignant Hyperthermia, Science, 253 (1991), pp. 448451. 
[14] K. Otsu, V. K. Khanna, A. L. Archibald, D. H. MacLennan: Cosegregation of porcine malignant hyperthermia and a probable causal mutation in the sceletal muscle ryanodine receptor gene in backcross families, Genomics, 11 (3) (1991), pp.744-750.

[15] Z. T. Popovski, B. Tanaskovska, K. Porchu, V. Vukovic, S. Andonov, B. Palasevski: New approach in detection of porcine stress syndrome, Biotechnolog in Animal Husbandry, 18 (5-6) (2002), pp. 73-80.

[16] Z. T. Popovski, B. Dimitrievska, S. Andonov, V. Vukovic, S. Domazetovska: Corelation between certain biochemical parameters and different genotypes for malignant hyperthermia in swine. First international symposium on animal science Belgrade, Serbia. Proceedings - Book of papers (2012) pp. 258-264.

[17] Z. T. Popovski, Z. Pejkovski, T. Nestorovski: Stress free populations deliver quality. Fleisch Wirtschaft International, 31 - 5, (2016), pp. 17-21.

[18] E. Jakob, Genetic Polymorphism of milk proteins, Mljekarstvo, 44 (3) (1994), pp. 197-217.

[19] Z. T. Popovski, B. Palasevski, N. DubrovaMateva, V. Andonovska, Z. Naletovski, Polymorphisms of $\kappa$--casein and $\beta$-lactoglobulin in cow milk, Symposia for Livestock production, Year Book (2001) pp. 45-50.

[20] A. Barroso, S. Dunner, J. Canon, Detection of Bovine Kappa Casein Variants A, B, C and E by Means of Polymerase Chain Reaction - Single Strand Conformation Polymorphism (PCR-SSCP), J. Anim. Sci., 76 (1998), pp. 1535-1538.

[21] J. C. Mercier, G. Brigman, D. Ribadeau, Primary structure of bovine $\kappa$-kasein B. Complete sequence, Eur. J. Biochem., 35 (1973), pp. 222-235.

[22] D. Morini, G. Losi, G. B. Castagnetti, P. Mariani, Cheese making experiments with milk characterized by kappa casein variants A and B: characteristics of the ripened cheese, Scien. Tecn. Latt.Casear, 30 (1979), pp. 243-262.

[23] B. Tanaskovska (Dimitrievska), K. Porcu, Z. T. Popovski, Frequency of $\kappa$-casein Genotypes in Holstein-Frisian Cattle in Republic of Macedonia, Biotechnology, Scientific Pedagogical Publishing, Ceske Budejovice, Czech Republic, (2006) ISBN 8085645-53-X pp. 415-417.

[24] H. E. Swaisgood, Chemistry of the caseins. In: Fox PF, editor. Advanced Dairy Chemistry. London: Elsevier, 1992, pp. 63-110.

[25] F. Pilla, C. Bevilacqua, C. Leroux, A. Fraghi, P. Martin: Genotiping of alpha s1 casein in sheep. Anim. Genet., 29 (1998), pp. 460-477.

[26] Z. T. Popovski, B. Dimitrievska, K. Porcu, M. Brka, A. Rustempasic, B. Markovic, R. Djedovic, V. Margeta, H. Mehmeti, M.Vegara: Polymorphisms in ovine $\alpha$ 1-casein gene among autoch- thon strains of Pramenka breed sheep in Balkan. International symposium for Agriculture and food (2013) Symposium proceedings pp. 687-690.

[27] B. Vaskov, G. Efremov, Fourth Haemoglobin Type in Sheep, Nature, 216 (1967), pp. 593-594.

[28] Z. T. Popovski, V. Dzabirski, S. Andonov, S. Trojacanec, Polymorphisms of some serum proteins and hemoglobin in conserved nucleus of Karakachan sheep in Macedonia, Symposia for Livestock production, Year Book, 2001, pp.87-91.

[29] G. Kahl, The Dictionary of Gene Technology. Wiley-WCH, Winheim (2001).

[30] K. Belkhir, P. Borsa, J. Goudet, L. Chikhi, F. Bonhomme, GENETIX, Montpellier, University of Montpelier, (1988).

[31] M. Cinkulov, Z. Popovski, K. Porcu, B. Tanaskovska, A. Hodzic, H. Bytyqi, H. Mehmeti, V. Margeta,R. Djedovic, A. Hoda, R. Trailovic, M. Brka, B. Markovic, B. Vazic, M. Vegara, I. Olsaker, J. Kantanen, Genetic diversity and structure of the West Balkan Pramenka sheep types as revealed by microsatellite and mitochondrialDNA analysis, J. Anim. Breed. Genet., 125 (2008), pp. 417-426.

[32] Min Du, R. J. McCormick, Taylor \& Francis Group, Applied muscle biology and meat science USA, (2009).

[33] T. Laas, In protein purification: principles, high resolution methods and applications (ed. J.-C. Janson and L. Ryden), VCH press, Weinheim (1989).

[34] J. C. Sawdy, S. A. Kaiser, N. R. St-Pierre, M. P. Wick, Myofibrillar 1-D fingerprints and myosin heavy chain MS analyses of beef loin at $36 \mathrm{~h}$ postmortem correlate with tenderness at 7 days, Meat Science, 67 (2004), pp. 421-426.

[35] T. Nestorovski, B. Tanaskovska, M. Wick, M. Svetozarevic, Z. T. Popovski, The influence of size and living temperatures on the muscle protein profile of koi carp (Cyprinus carpio haematopterus). II International Symposium for Agriculture and Food. Book of abstracts, Ohrid (2015). pp.355.

[36] L. M. Z. Chicharo, M. A. A. T Chicharo, The DNA/RNA ratio as a useful indicator of the nutritional condition in juveniles of Ruditapes decussatus, Sarda, R., Ros, J.D. (Eds.), Scientia Marina, (1995), pp. 95-101.

[37] Z. T. Popovski, K. Kwasek, M. Wojno, K. Dabrowski, B. Tanaskovska, S. Andonov, M. Wick: Determination of RNA DNA ration in white muscle samples of Koi carp using different techniques. II International Symposium for Agriculture and Food, October 2015, Ohrid. Book of abstracts, p.349.

[38] S. Surinova, R. Schiess, R. Huttenhain, F. Cerciello, B. Wollscheid, R. Aebersold, On the Development of Plasma Protein Biomarkers, J. Proteome Res.,10 (2011), pp. 5-16. 
[39] Z. T. Popovski, B. R. Dimitrievska, E. Miskoska Milevska, K. Bandzo: Electrophoretic determination of female specific protein in koi carp as a tool for gender identification: Technique comparison, International Symposium for Agriculture and Food, Symposium Proceedings, (2013), pp. 691695.

[40] G. Mennella., V. OnofaroSanaja, A. Tonnini, V. Magnifico, Seed storage protein characterization of Solanum species and of cultivars and androgenetic lines of $S$. melanogena L. by SDS-PAGE and AE-HPLC, Seed Sci. Technol., 27 (1999), pp.2335 .

[41] A. Hussain, Interlines variation of electrophoregrams of cotyledon protein of field bean, Euphitica, 39 (1988), pp.109-113.

[42] E. Miskoska-Milevska, Z. T. Popovski, B. Dimitrievska, K. Porcu, Differences in Tomato Seed Protein Profiles Obtained by SDS PAGE Analysis, J. Agricul. Sci., 53 (2008), pp. 13-23.

[43] A. E. Alvarez, C. C. M. Van De Wiel, M. J. M. Smulders, B. Vosman, Use of microsatellites to evaluate genetic diversity and species relationships in the genus Lycopersicon, Theor. Appl. Genet., 103 (2001), pp. 1283-1292.

[44] E. Miskoska - Milevska, Z. T. Popovski, Blagica R. Dimitrievska, K. D. Porcu, Isolation of DNA for fragment analyses from tomato leaves and seeds. XVI International Conference of Biotechnology with international participation, Faculty of Agronomy, Čačak, 2011, pp. 59-64.

[45] E. Miskoska - Milevska, Z. T. Popovski, T. Nestorovski, Usefulness of a locus LE21085 in the genetic differentiation of tomato varieties, Genetika, 9 (2) (2017), pp. 2019-2023.

[46] M. Slatkin, A measure of population subdivision based on microsatellite allele frequencies, Genetics, 139 (1) (1995), pp. 457-462.

[47] E. Miskoska - Milevska, Z. T. Popovski, Blagica R. Dimitrievska, K. D. Porcu., K. Bandzo, Determination of genetic diversity among different tomato varieties using SSR markers, Acta Agriculturae Serbica, Vol. XVI, 31 (2011), pp. 9-17.

[48] G. Parrella, N. Acanfora, M. G. Bellardi, First Record and Complete Nucleotide Sequence of Alfalfa mosaic virus from Lavandula stoechas in Italy, Plant Disease - Disease Notes, 94 (7) (2010), p. 924.

[49] K. Bandzo, R. Rusevski, B. Kuzmanovska, S. Bandzo, E. Miskoska-MIlevska, Z. T. Popovski,
Serological approach in the detection of viruses in pepper plants cultivated on open fields in the Republic of Macedonia. International Scientific Conference "Challenges in Modern Agricultural Production", Book of abstracts, 2014, p. 62.

[50] B. (Dimitrievska) Tanaskovska, K. Porcu, Z. T. Popovski: Development of a System for GMO Testing of Food, Seed and Feed Samples in the Republic of Macedonia, XI Savetovanje o Biotehnologiji, 2006, pp. 665-669.

[51] G. J. van Duijn, R. Van Biert, H. BleekerMarcelis, I. Van Boeijen, A. J. Adan, S. Jhakrie, M. Hessing, Detection of genetically modified organisms in foods by protein and DNA-based techniques: bridging the methods, J. AOAC Int. 85 (3) (2002): pp. 787-91

[52] 3. Поповски,Э. Мискоска-Милевска, Т. Несторовски,Е. В. Камалдинов,В. Л. Петухов: Подходы к обнаружению генно-модифицированной кукурузы и проведению полуколичественного анализас использованием белка CP4 EPSPS. (Approaches to investigation of gene modified maize and semi-quantative analysis by means of CP4 EPSPS protein). Вестник НГАУ, 3 (40) (2016), pp. 92-97.

[53] B. Dimitrievska, Z. T. Popovski, K. Porcu: Merging procedures for detection of soy DNA and presence of GM soy in food samples. Foodinova 2010, Valencia, Spain (2010), pp.146.

[54] M. Svetozarevic, T. Nestorovski, Z. T. Popovski, Electrophoretic distinction of the origin in different dairy products and milk samples. International Symposium on Animal Science, Beograd, Serbia, September 23-25, Proceedings of papers, (2014). pp. 551-557.

[55] I. Irfan, A. Arslan, Identification of Meat Species by Polymerase Chain Reaction Technique, Turkish Journal of Veterinary and Animal Science, 31 (3) (2007), pp. 159-163.

[56] Z. S. Musliji, M. Svetozarevic, T. Nestorovski, B. R. Tanaskovska, Z. T. Popovski, Different approaches in the identification of meat origin based on protein profiling and simple PCR. II International Symposium for Agriculture and Food (2015) Ohrid. Book of abstracts, pp.142.

[57] J. S. Fruton, A history of pepsin and related enzymes, Q. Rev. Biol., 77 (2) (2002), pp. 127-47

[58] T. Nestorovski: Determination of purity and concentration of chymosin and its equivalents in commercial samples. Master work (2017) 43 pp. 


\title{
ПРИМЕНА НА МОЛЕКУЛАРНИ АЛАТКИ ВО СТОЧАРСТВОТО, ЗЕМЈОДЕЛСТВОТО, КОНТРОЛАТА НА ХРАНА И ВО АГРОБИОДИВЕРЗИТЕТОТ ВО РЕПУБЛИКА МАКЕДОНИЈА
}

\author{
Зоран Т. Поповски ${ }^{1,5}$, Благица Танасковска ${ }^{1}$, Елизабета Мискоска - Милевска ${ }^{2}$, Томе \\ Несторовски ${ }^{1}$, Кочо Порчу ${ }^{3}$, Катерина Банџо - Орешковиќ ${ }^{4}$, Милица Светозаревиќ $^{5}$, Зимера \\ Саити ${ }^{5}$, Macdonald Wick ${ }^{6}$
}

${ }^{1}$ Катедра за биохемија и генетско инженерство, Факултет за земјоделски науки и храна, Универзитет „Св. Кирил и Методиј“, Скопје, Република Македонија

${ }^{2}$ Катедра за квалитет и безбедност на храна, Факултет за земјоделски науки и храна, Ss. Cyril and MethodiusUniversity, Skopje, Republic of Macedonia

${ }^{3}$ Катедра за сточарство, Факултет за земјоделски науки и храна, Универзитет „Св. Кирил и Методиј“, Скопје, Република Македонија

${ }^{4}$ Одделение за заштита на растенија, Земјоделски институт, Универзитет „Св. Кирил и Методиј“, Скопје, Република Македонија

5 Лабораторија за протеинска и ДНК технологија,Технолошко-металуршки факултет, Универзитет „Св. Кирил и Методиј“, Скопје, Република Македонија

${ }^{6}$ Оддел за сточарство, Факултет за земјоделство, животна средина и храна, Државен универзитет

Охајо, Колумбус, Охајо, САД

\begin{abstract}
Молекуларните методи претставуваат незаменливи фактори за унапредување на производството на храна, како и за нејзина контрола. Катедрата за биохемија и генетско инженесрство (КБГИ) при Факултетот за Земјоделски науки и храна има клучна улога во постојаната примена на молекуларни техники во разчни области на земјоделското и сточарското производсвто. КБГИ главно се занимава со селекција со примена на маркери (СПМ), еволуциони студии, идентификација на потеклото на разни видови храна, анализа на ензими употребувани при преработка на храна, генска експресија, молекуларна детекција на растителни вируси и ГМО-анализи. Целни молекули на применуваните техники се протеините, молекулите на РНК и ДНК. СПМ системски се применува во Македонија при одгледување на животни, користејќ́ ги гените за: RYR-1, к и $\alpha \mathrm{S} 1-$ казеин. Еволуционите студии беа вршени користејќи ДНК микросателити со цел да се определи генетската сродност меѓу различни автохтони видови на овци и вариетети на домати. Идентификација на потеклото на храна и идентификација на полот на риби беше вршено преку техники за анализа на протеински профили. Генската експресија беше анализирана преку разни фактори и инхибитори за раст на нивото на РНК. Во лабораторијата за биохемија и молекуларна биологија се анализирани повеќе од 3.000 примероци од растително и анимално потекло. Лабораторијата за ГМО како дел од КБГИ е првата овластена лабораторија за анализирање на ГМО во храна и во добиточна храна. За овие анализи за повеќе од 100 примерока се користени Real Time - PCR (RT PCR) методи.
\end{abstract}

Клучни зборови: добиток; земјоделски култури; храна; молекуларни техники; Македонија 